\title{
STUDIES IN THE VASCULAR FLORA OF THE SOUTHEASTERN UNITED STATES. VII
}

\author{
Alan S. Weakley, Derick B. Poindexter, Hannah C. Medford
}

UNC-CH Herbarium (NCU), North Carolina Botanical Garden, University of North Carolina at Chapel Hill

Campus Box 3280, Chapel Hill, North Carolina 27599-3280, U.S.A.

weakley@unc.edu,dbpoindexter@gmail.com, hcmedford@gmail.com

\author{
Alan R. Franck \\ Institute of Environment, Department of Biological Sciences, Florida International University \\ 11200 SW 8th Street, Miami, Florida 33199, U.S.A., afranck@fiu.edu \\ Keith A. Bradley \\ South Carolina Department of Natural Resources, Heritage Trust Program, 1000 Assembly Street \\ Columbia, South Carolina 29202, U.S.A. and \\ A.C. Moore Herbarium (USCH), University of South Carolina, BradleyK@dnr.sc.gov
}

Jimi Sadle

Everglades and Dry Tortugas National Parks, 40001 State Road 9336

Homestead, Florida 33034, U.S.A. Jimi_sadle@nps.gov

John Michael Kelley

8012 Blanchard Furrh Road, Shreveport, Louisiana 71107, U.S.A.

kelley.johnmichael@gmail.com

\begin{abstract}
As part of ongoing efforts to understand, document, and conserve the flora of southeastern North America, we propose two new species, the recognition of a usually synonymized variety, the acceptance of two species of Waltheria as being present in peninsular Florida, taxonomic acceptance of a sometimes deprecated species transferred with a new name into a different genus, and we clarify the distribution and ecology of a species. In Carex (Cyperaceae), we re-analyze infrataxa in Carex intumescens and recommend the recognition of two varieties, a taxonomic schema first proposed in 1893, but usually not followed in the 128 years since. In Euphorbia (Euphorbiaceae), a careful assessment of south Florida material of Euphorbia subg. Chamaesyce sect. Anisophyllum subsect. Hypericifoliae reveals the need for taxonomic changes to best classify endemic representatives of this group, resulting in the naming of a new species, and a new name at species rank in Euphorbia for a taxon first named in Chamaesyce and sometimes subsequently treated at only varietal rank in Euphorbia. Chamaecrista deeringiana (Fabaceae, subfamily Caesalpinioideae) has been repeatedly misinterpreted to include two different and disjunct population systems with differing morphologies and habitats, which are here interpreted as separate species, one newly named and the other Chamaecrista deeringiana returned to its original and narrower interpretation as a south Florida endemic. Waltheria (Malvaceae) has sometimes been interpreted as being represented in Florida by a single taxon, Waltheria indica, but we disentangle the concepts of the widespread W. indica and the West Indian W. bahamensis and clarify that both are present in the southeastern United States. We reconsider the occurrence and habitat of Toxicoscordion nuttallii (Melanthiaceae) in three states in which it has been reported as a rare species, Mississippi, Missouri, and Louisiana, and remove it from the Mississippi flora as a garbled and false report. In Louisiana, its occurrence in calcareous prairie complexes limits its potential occurrence in the state to a specialized and rare habitat, but careful exploration of habitat remnants may result in the discovery of additional populations. Taxonomic studies and re-assessments of this kind are critical in laying the best scientific foundation for regulatory, policy, and land conservation decisions. This paper names or makes the case for the renewed acceptance of six species with range-wide conservation concern: one Critically Imperiled (G1 - Euphorbia ogdenii), one Imperiled (G2 - E. hammeri), and four Vulnerable (G3 - E. garberi, E. porteriana, Chamaecrista deeringiana, C. horizontalis).
\end{abstract}

\section{RESUMEN}

Como parte de los esfuerzos para comprender, documentar y conservar la flora del sureste de América del Norte, proponemos dos nuevas especies, el reconocimiento de una variedad generalmente sinonimizada, la aceptación de dos especies de Waltheria presentes en 
la península de Florida, la aceptación taxonómica de una especie a veces en desuso se transfiere con un nuevo nombre a un género diferente y se aclara la distribución y ecología de una especie. En Carex (Cyperaceae), re-analizamos los taxones infraspecíficos en Carex intumescens y recomendamos el reconocimiento de dos variedades. Este esquema taxonómico propuesto por primera vez en 1893, pero, no seguido en general en los 128 años posteriores. En Euphorbia (Euphorbiaceae), una evaluación cuidadosa del material del sur de Florida de Euphorbia subg. Chamaesyce sect. Anisophyllum subsect. Hypericifoliae revela la necesidad de cambios taxonómicos para clasificar mejor a los representantes endémicos de este grupo, lo que resulta en el nombramiento de una nueva especie, y la propuesta de un nuevo nombre en el rango de especie en Euphorbia para un taxón nombrado por primera vez en Chamaesyce y tratado posteriormente con solo rango varietal en Euphorbia. Chamaecrista deeringiana (Fabaceae, subfamilia Caesalpinioideae) ha sido repetidamente malinterpretada para incluir dos sistemas de poblaciones diferentes y disjuntos con diferentes morfologías y hábitats, que aquí se interpretan como especies separadas, una recién nombrada y la otra Chamaecrista deeringiana volvió a su interpretación original y más estrecha como un endemismo del sur de Florida. Waltheria (Malvaceae) a veces se ha interpretado como representada en Florida por un solo taxón, Waltheria indica, pero desentrañamos los conceptos de la extendida W. indica y W. bahamensis de las Indias Occidentales. Aclaramos, que ambas están presentes en el sureste de los Estados Unidos. Reconsideramos la ocurrencia y el hábitat de Toxicoscordion nuttallii (Melanthiaceae) en tres estados en los que se ha reportado como especie rara, Mississippi, Missouri y Louisiana, y lo eliminamos de la flora de Mississippi donde se basaba en una cita confusa y errónea. En Luisiana, su ocurrencia en complejos de praderas calcáreas limita su posible ocurrencia en el estado a un hábitat especializado y raro. La exploración cuidadosa de los restos de hábitat puede resultar en el descubrimiento de poblaciones adicionales. Los estudios taxonómicos y las reevaluaciones de este tipo son fundamentales para sentar las mejores bases científicas para las decisiones regulatorias, y políticas de conservación del territorio. Este documento nombra o argumenta a favor de la aceptación renovada de seis especies con preocupación de conservación en todo el rango: una en peligro crítico (G1 - Euphorbia ogdenii), una en peligro (G2 - E. hammeri) y cuatro vulnerables (G3 - E. garberi, E. porteriana, Chamaecrista deeringiana, C. horizontalis).

\section{INTRODUCTION}

As part of ongoing work on the Flora of the southeastern United States (Weakley 2020), as well as for general floristic, conservation, and scientific work in eastern North America, it is necessary or desirable to document taxonomic and nomenclatural changes and notable distribution records. In some cases, new combinations are needed to accurately reflect current taxonomic understanding. Some of these are rank changes, whereas others are generic transfers to apply new (or old) generic concepts to taxa that do not have corresponding available names at the specific or infraspecific rank. We have also addressed various nomenclatural issues and clarified characters and identification of difficult groups in the regional flora.

We here present a seventh volume of such changes, contributed by nine authors. It follows similar conventions and philosophical approaches as the earlier volumes in the series (Weakley et al. 2011, 2017, 2018a, $2018 b, 2019,2020$ ). Primary authorship of the sections in this paper is as follows (and is also indicated at the beginning of each section): Carex (HCM, DBP, \& ASW), Euphorbia (KAB \& JS), Chamaecrista (ARF), Waltheria (ARF), and Toxicoscordion (JMK).

\section{CYPERACEAE}

Carex: A morphometric analysis of the Carex intumescens complex supporting the recognition of two varieties.

Primary authors: H.C. Medford, Derick B. Poindexter, and Alan S. Weakley

Carex intumescens Rudge (Cyperaceae sect. Lupulinae Tuck. ex J. Carey) has an extensive range across eastern North America, from Newfoundland west to Manitoba, Minnesota, western South Dakota and northeastern Colorado, and thence south to central peninsular Florida and eastern Texas (Reznicek \& Ball 1974; Reznicek 2002; Kartesz 2015).

Within C. intumescens, one variety, C. intumescens var. fernaldii L.H. Bailey, has been described based on populations from Maine (Bailey 1893). Compared with typical var. intumescens, this taxon purportedly has slimmer and fewer perigynia per pistillate spike, as well as narrower leaves (Bailey 1893). Fernald (1942) expanded upon this morphological concept and used achene shape as a significant distinguishing feature, attributing elliptic achenes to var. intumescens and obovoid achenes to var. fernaldii. Confusingly, Fernald (1942) described a form of $C$. intumescens var. fernaldii (=f. ventriosa), which resembles typical C. intumescens in all characters except for the obovoid achenes he associated with var. fernaldii (Fernald 1942). Uttal (1971) found an additional feature, the curvature of achene styles, to support recognizing var. fernaldii. 
Biogeographically, all authors interpreted var. intumescens as occurring predominantly at lower latitudes and var. fernaldii as distributed at upper latitudes.

In contrast to these observations, Reznicek and Ball (1974) found no difference in achene shape between var. fernaldii and var. intumescens and therefore rejected var. fernaldii as a distinct taxonomic entity within C. intumescens. Likewise, in our preliminary assessments we found that style morphology (as emphasized by Uttal [1971]) was unrelated to perigynium shape, achene shape, geography, or habitat, while also being difficult to quantify in a replicable way.

Since the description of var. fernaldii, a majority of floristic treatments or studies have treated C. intumescens as an indivisible species, with var. fernaldii synonymized (Mackenzie 1931-1935; Small 1933; Gleason 1952; Radford et al. 1968; Godfrey \& Wooten 1979; Gleason \& Cronquist 1991; Ball \& Reznicek 2002; Rhoads \& Block 2007; Haines 2011; Weakley et al. 2012; Voss \& Reznicek 2012), likely owing to the lack of clarity surrounding its description. A minority of floristic treatments list $C$. intumescens as having two varieties (Robinson \& Fernald 1908; Fernald 1950; Tennessee Flora Committee 2015; Weakley 2020; Weakley et al. 2020a).

It is evident that considerable morphological variation occurs within the species, likely driving the original description of infraspecific taxa. However, distinguishing features and correlated biogeography have not been investigated rigorously enough to confidently circumscribe meaningful taxonomic units.

After years of qualitative field observations throughout the southeast by the second and third authors, coupled with cursory examinations of herbarium specimens, we chose to embark on a morphometric study to potentially clarify taxonomic units within $C$. intumescens. This need was particularly evident when juxtaposing populations of plants across multiple elevations and physiographic provinces. In the Southern Appalachians specifically, we have noticed that there seem to be two entities with different morphologies correlated with different habitats. Plants with slimmer perigynia (possibly var. fernaldii) are found in high-elevation non-wetland sites, notably in spruce-fir forests, northern hardwood forests, and grassy balds, compared to plants with more robust perigynia (typical of var. intumescens), which are found in high- to low-elevation wetland sites (Uttal 1971; Weakley 2020). Here, we assess the morphological variation within C. intumescens and assign discrete morphological groups appropriate taxonomic ranks.

We analyzed 263 herbarium specimens, which encompassed the full geographic distribution of Carex intumescens, from the following herbaria: MICH, NCU, TEX, and USF. We also examined type material of $C$. intumescens var. fernaldii $(\mathrm{GH})$ and gathered approximate measurements digitally from the putative holotype of $C$. intumescens var. intumescens (BM). To analyze morphological variation, we made 1 discrete, 2 ratio, and 10 continuous morphological measurements (Table 1).

We performed a Principal Component Analysis (PCA) in PC-ORD (McCune \& Mefford 2011) to elucidate different groups present evident via separation on ordination space. The PCA was based on a correlation distance-based biplot and only used continuous or ratio variables. We excluded from the final PCA characteristics that were not present on all specimens (e.g. subtending bract length, culm height) and other non-informative variables (Table 1). We used preliminary PCAs to ascertain groupings and compiled ranges and standard deviations for each entity present (Table 1). We used these ranges to refine the groups on a specimento-specimen basis and ran the final PCA.

Two imperfectly separated groups are depicted in our final PCA (Fig. 1), one of which includes the isotype specimens of $C$. intumescens var. fernaldii and the other containing the putative holotype of $C$. intumescens var. intumescens. We found the strongest determining morphological characteristics between these two varieties to be perigynium length-to-width ratio, perigynium width, and perigynium scale length. Two of these relate to perigynium dimensions: var. fernaldii has slimmer perigynium compared to var. intumescens, which is reflected in a higher perigynium length/width ratio and narrower perigynium widths (Figs. $2 \& 3$ ). This, along with the lower number of pergynia per pistillate spike (measured as max number of perigynia per pistillate spike here, but excluded from PCA as a noncontinuous variable), fits Bailey's original description of $C$. intumescens var. fernaldii (Bailey 1893). We found an additional characteristic (perigynium scale length) to be reliably useful in making determinations between var. fernaldii and var. intumescens (Figs. $2 \& 3$ ). However, we did not find any significant trend in achene characteristics, in agreement with Reznicek and Ball (1974). 
TABLE 1. Carex intumescens. Means $\pm 1 S D$ and ranges for each morphological character measured. Asterisks mark those specimens used in the PCA ( $n=267)$.

C. i. var. fernaldii $(\mathrm{n}=49)$

$4.91 \pm 0.80(3.3-6.2)$
$5.45 \pm 1.49(2-8)$
$11.69 \pm 1.14(9.10-14.00)$
$3.61 \pm 0.40(2.87-4.27)$
$3.26 \pm 0.39(2.8-4.5)$
$4.49 \pm 0.46(3.6-5.4)$
$2.81 \pm 0.39(2.3-4.1)$
$1.61 \pm 0.17(1.29-1.96)$
$24.69 \pm 7.70(12.0-45.0)$
$9.84 \pm 2.50(5.0-15.5)$
$2.71 \pm 0.62(1.6-4.4)$
$5.36 \pm 0.50(3.90-6.00)$
$60.14 \pm 16.34(31.8-102.8)$
$2.20 \pm 0.28(1.75-2.79)$

C. i. var. intumescens $(\mathrm{n}=213)$
1. Width of widest leaf $(\mathrm{mm})^{*}$

2. Maximum number of perigynia per pistillate spike (count)

3. Perigynium length $(\mathrm{mm})^{*}$

4. Perigynium width $(\mathrm{mm})^{*}$

5. Perigynium length/width ratio $(\mathrm{mm})^{*}$

6. Achene total length $(\mathrm{mm})$

7. Achene length to widest point $(\mathrm{mm})$

8. Achene total length/length to widest point (ratio)

9. Longest staminate spike length $(\mathrm{cm})$

10. Subtending bract length $(\mathrm{cm})$

11. Subtending bract width $(\mathrm{mm})$

12. Perigynium scale length $(\mathrm{mm})^{*}$

13. Culm height $(\mathrm{cm})$

14. Perigynium length/scale length (ratio)*
$4.92 \pm 0.87(2.9-7.9)$
$8.29 \pm 3.09(3-17)$
$11.59 \pm 1.20(8.67-15.17)$
$4.53 \pm 0.55(2.90-6.00)$
$2.58 \pm 0.33(1.8-3.9)$
$4.50 \pm 0.50(3.1-6.4)$
$2.58 \pm 0.38(1.4-3.6)$
$1.76 \pm 0.20(1.26-2.43)$
$33.22 \pm 11.7(4.4-70.0)$
$12.18 \pm 4.05(4.8-29.2)$
$2.86 \pm 0.67(1.1-6.0)$
$6.80 \pm 1.41(4.00-12.47)$
$64.18 \pm 16.17(26.1-127.9)$
$1.76 \pm 0.34(1.03-2.94)$

We also documented a broad range of morphological variation within C. intumescens var. intumescens. Most noticeably, previous literature described C. intumescens var. intumescens with fewer perigynia per pistillate spike and smaller perigynium scales (Rezineck \& Ball 1974; Ball \& Reznicek 2002) than we have documented. This is important, because some $C$. intumescens var. intumescens specimens with many perigynium per pistillate spike may be confused with the closely related C. grayi. However, $C$. intumescens can be distinguished by the glabrous surface of perigynia, whereas $C$. grayi has a puberulent vestiture visible under magnification (pers. obs.).

We created a map in ArcMap (ESRI 2017) to reflect the geographic range of these entities. Carex intumescens var. intumescens has an extensive range across all of eastern North America. Contrastingly, C. intumescens var. fernaldii is restricted to the northern regions of the range of the typical variety, only extending southward in the high elevations of the Appalachian Mountains (Fig. 4). This geographic pattern of var. fernaldii is supported by the habitat information provided on herbarium labels. Carex intumescens var. fernaldii is increasingly restricted to high-elevation spruce-fir forests at lower latitudes, while $C$. intumescens var. intumescens is widespread across a variety of habitats.

We did not find evidence for a clear northern/southern latitudinal separation, like that which Fernald (1942) proposed. This lack of the latitudinal separation is in agreement with Reznicek and Ball (1974). Carex intumescens var. intumescens is widespread throughout (Fig. 4) and exhibits a broad range of morphological variation. Similarly, C. intumescens var. fernaldii is not restricted to northern latitudes (Fig. 4). However, it may appropriately be considered a "northern" variety since it extends south in only high-elevation habitats typically mimicking northern latitudes, such as spruce-fir forests (Schafale 2012). Reznicek and Ball (1974) discredited a geographic pattern present in either variety, but they primarily looked at northern material, and this pattern was not apparent until southern material was examined.

The imperfect morphological separation of the two entities (Fig. 1) suggests that either no taxonomic recognition should be given to them, or that a lower rank (e.g., variety) is warranted rather than a higher rank (i.e., species). However, the two entities do exhibit a strong geographic and habitat separation, especially in the southeastern United States. Var. intumescens is widely and generally distributed, and seemingly found only in wetlands. In contrast, var. fernaldii appears to be restricted to high-elevation sites in the Southern Appalachians that are moist but not wetlands (Fig. 4). By not recognizing these morphologically and ecologically differentiated entities, we lose valuable understanding of the biological diversity in this complex.

Our awareness of cryptic and semicryptic species is increasing with modern taxonomic studies, which employ tools like high-throughput genetic analysis. "Cryptic" refers to taxa that warrant specific rank but differ (only or primarily) on genetic or micromorphological levels (Bickford et al. 2007). It is completely possible 


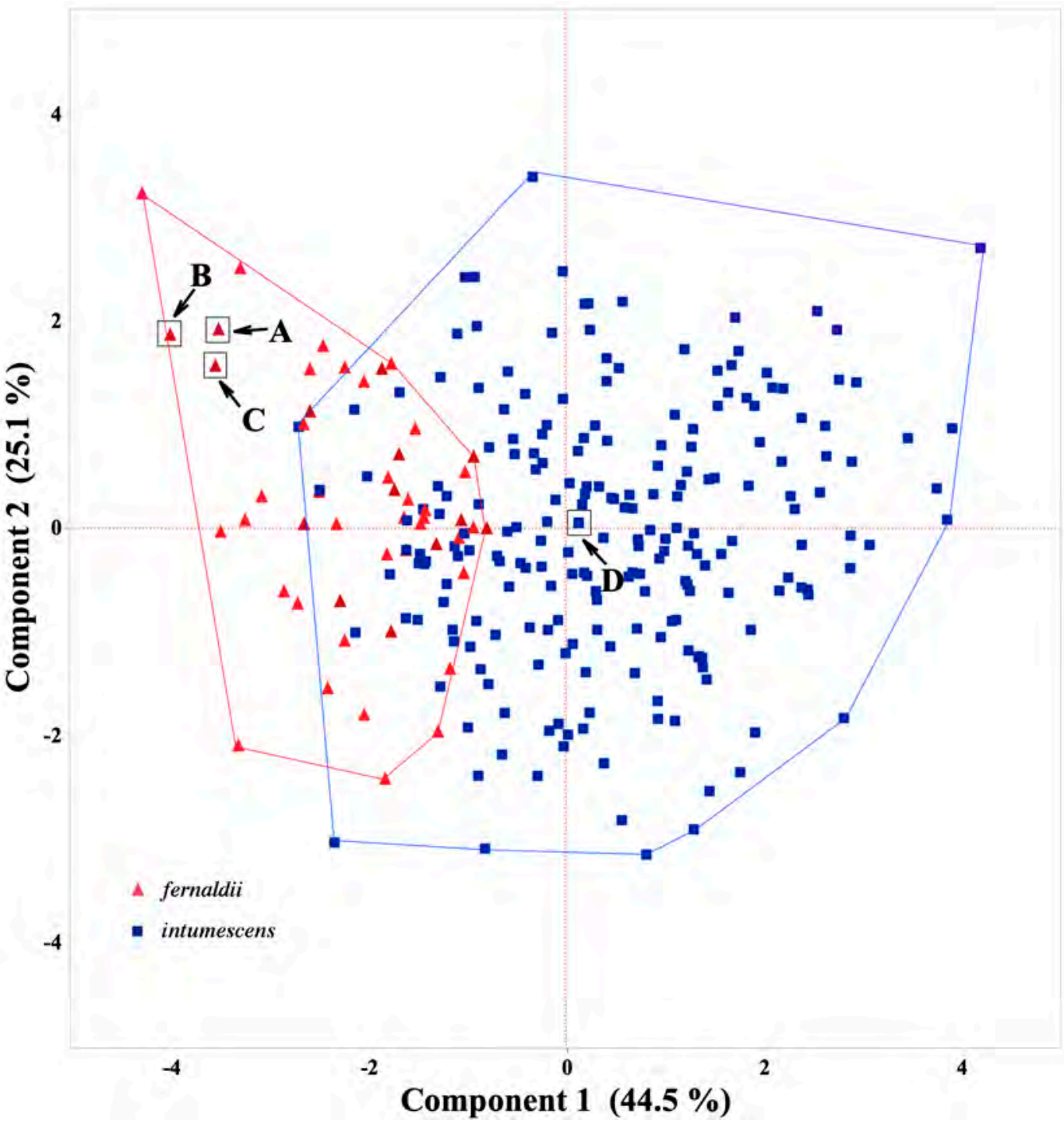

FiG. 1. Scatterplot of principal components 1 and 2. Type specimens of $C$. intumescens var. fernaldii (Holotype: Fernald 127, A=GH-00254854 and Isotypes: $\mathrm{B}=\mathrm{GH}-00027284, \mathrm{C}=\mathrm{GH}-00254854)$ and var. intumescens ( $\mathrm{D}=$ Holotype: Fraser s.n., BM-001042058) are marked by arrows. Components 1 and 2 account for $44.5 \%$ and $25.1 \%$ of the variation, respectively ( $69.6 \%$ of the variation combined).

that the two entities discussed here represent semicryptic species. To address this, data from genetic analyses could be compared with an expanded set of morphological characters. This would help conclusively ascribe biologically accurate ranks for these two entities. However, until such study is done, it seems best to conservatively represent these entities at varietal rank. This maintains their names and taxonomic concepts but avoids overstating their taxonomic status, pending further study. In NatureServe conservation ranks, we consider both taxa to warrant G5T5 rangewide ranks: The species as a whole is G5, and each variety is T5: Globally Secure. 


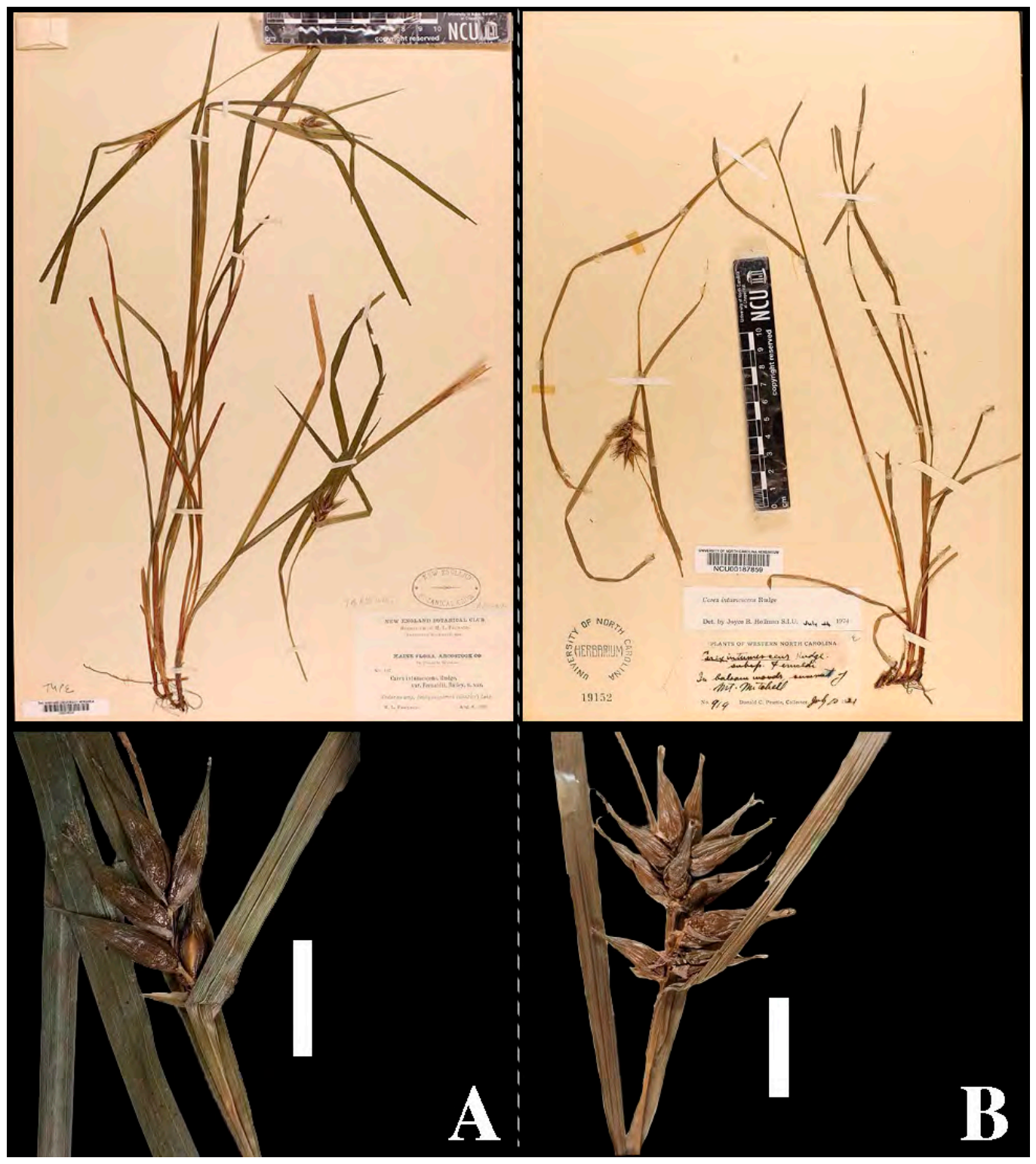

FIG. 2. Images of Carex intumescens var. fernaldii. A. GH-00254854 (Holotype: Fernald 127) and B. NCU-00187859 (Peattie 919 ). Scale bars= $1 \mathrm{~cm}$.

KEY TO CAREX INTUMESCENS VARIETIES

1. Perigynium length/width ratio (2.8-)3.0-4.5; perigynia 2.9-3.0(-4.3) $\mathrm{mm}$ wide; maximum number (on a plant) of perigynia per pistillate spike 2-7(-8); perigynium scale length 3.9-5.8(-6.0) $\mathrm{mm}$; [widespread in the northern US and adjacent Canada, but southwards of New York restricted to moist (but not wetland) high elevation habitats such as spruce-fir forests]

C. intumescens var. fernaldii

1. Perigynium length/width ratio 1.8-2.9(-3.9); perigynia (2.9-)4.0-6.0 mm wide; maximum number (on a plant) of perigynia per pistillate spike (3) 6-17; perigynium scale length (4.0-)5.0-12.5 mm; [widely distributed in wetlands throughout eastern North America] 


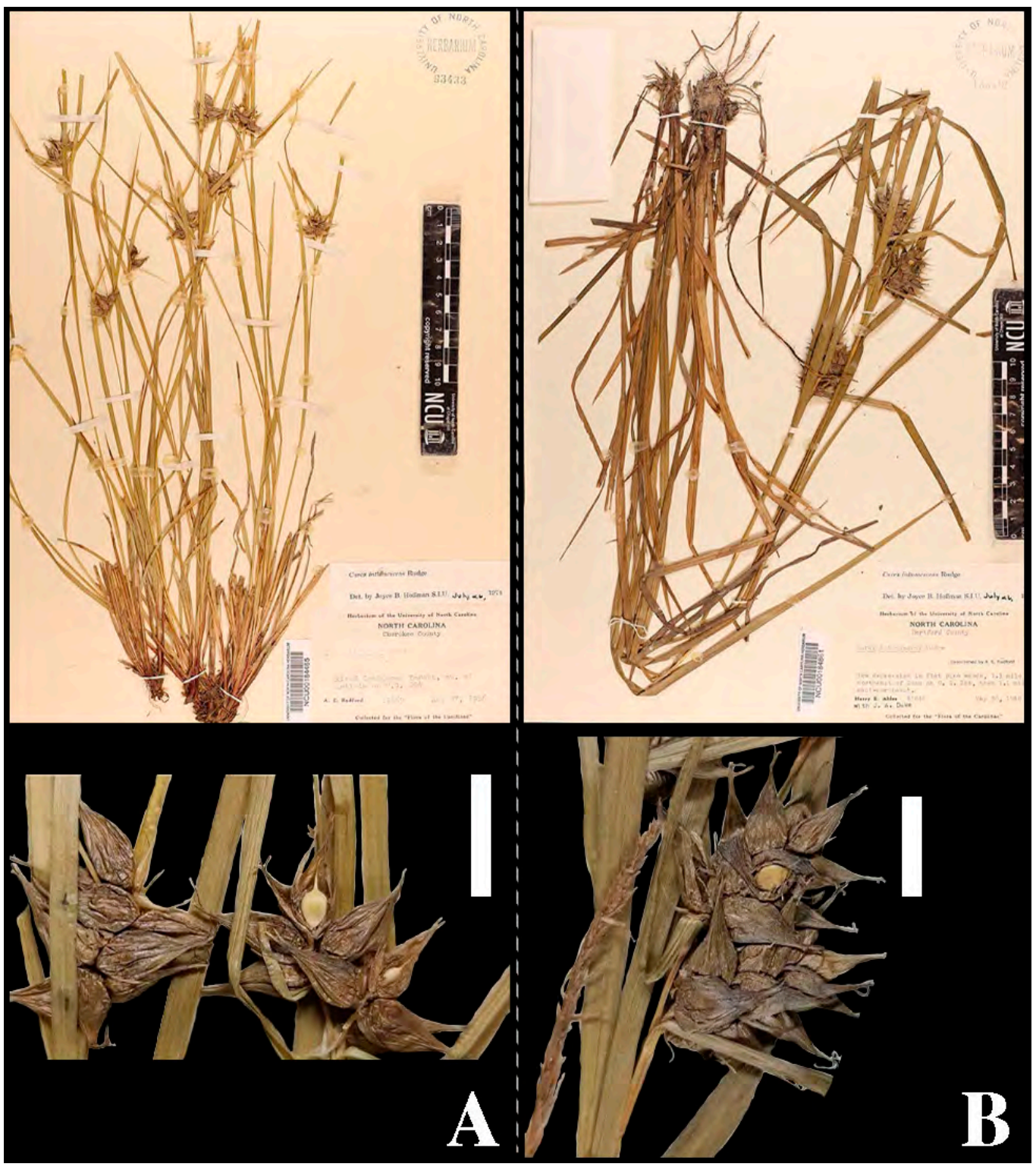

Fig. 3. Images of Carex intumescens var. intumescens. A. NCU-00184465 (Radford 11669) and B. NCU-00184861 (Ahles 41645 ). Scale bars=1 cm.

\section{Specimens Examined}

\section{Carex intumescens var. fernaldii}

CANADA. NEW BRUNSWICK. Kent Co.: 25 Jul 1978, Munro 2041 (NCU). ONTARIO. Manitoulin Co.: 15 Aug 1932, Grassl 4617 (MICH); 29 Nov 1959 Soper 9051 (NCU). Thunder Bay District: 12 Jul 1979, Garton 18896 (MICH). QUEBEC. Sainte-Foy: 12 Aug 1977, Baillargeon 1333 (MICH). U.S.A. Maine. Aroostook Co.: 8 Aug 1893, Fernald 127 (GH); 8 Aug 1893, Fernald 127 (GH). Piscataquis Co.: 8 Jun 1929 , Ewer s.n. (NCU). MASSACHUSETTS. Berkshire Co.: 13 Jul 1915, Watters s.n. (NCU). MICHIGAN. Crawford Co.: 12 Jun 1955 , Hebert s.n. (MICH); 23 Jul 1887, Hicks s.n. (MICH). Delta Co.: 4 Jul 1976, Kopple 83 (MICH). Dickinson Co.: 20 Jun 1959, Voss 8556 (MICH). Iron Co.: 13 Jun 1955, Hebert s.n. (MICH). Kalkaska Co.: 12 Jul 1956, Voss 3041 (MICH). Kent Co.: 3 May 1894, Cole s.n. (MICH). Menominee Co.: 18 


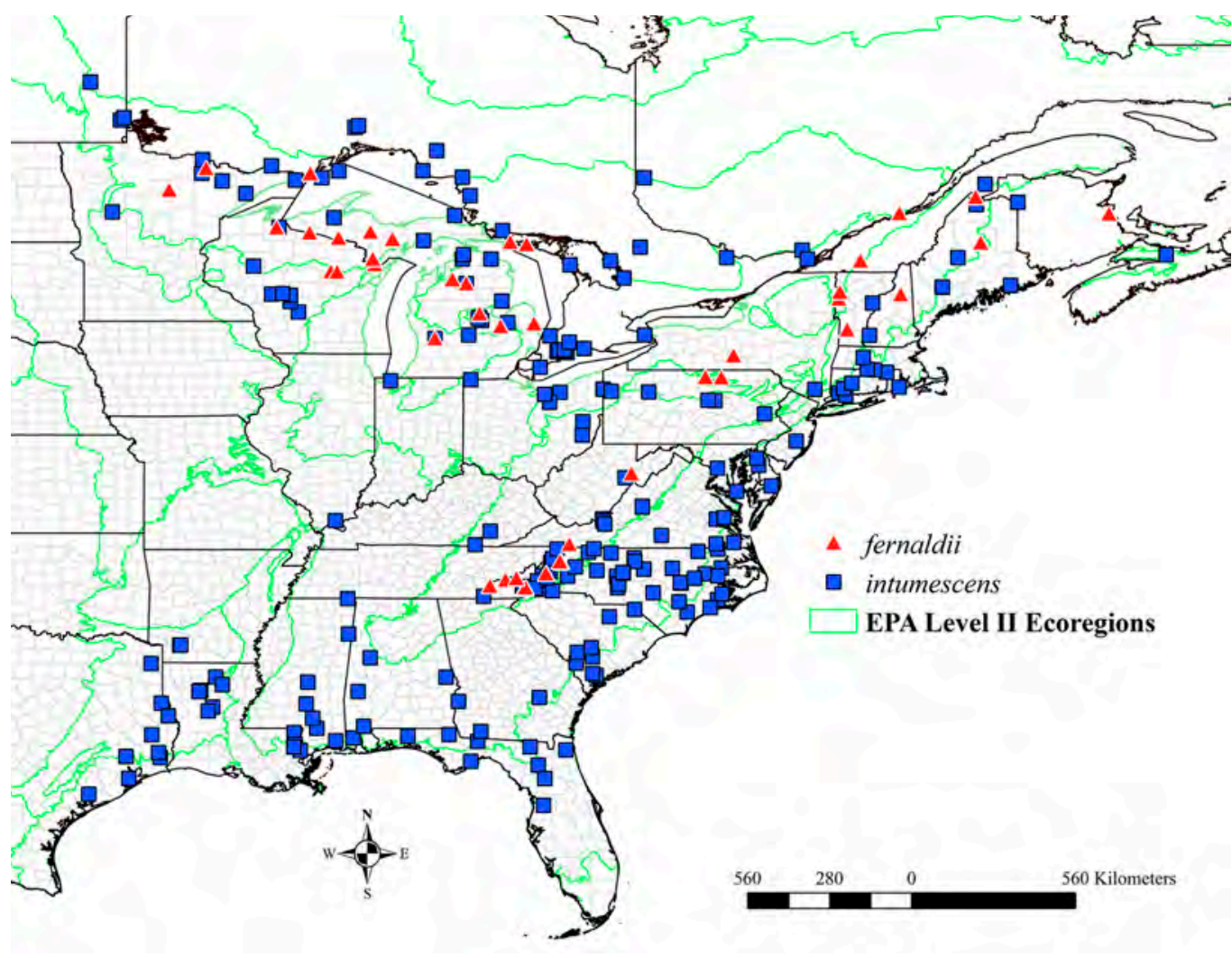

FIG. 4. Range map of the Carex intumescens complex delineated into EPA Level II Ecoregions. Individual points correspond to voucher specimens examined in this study.

Aug 1933, Grassl 3557 (MICH); 5 Sep 1936, Grassl 7956 (MICH). Midland Co.: 27 Jun 1928, Dreisbach 5985 (MICH). Sanilac Co.: 19 Jun 1958, Voss 6691 (MICH). Tuscola Co.: 2 Jun 1962, Hiltunen 3970196 (MICH). MINNESOTA. Cass Co.: 16 Jun 1978, Ownbey 5876 (NCU). Louis Co.: 25 Jun 2014, Smith \& Gerdes 35010 (MICH). NEW HAMPSHIRE. Coos Co.: 22 Aug 1974, Boufford 15380 (NCU). NEW YORK. Ithaca Co.: Jun 1903, Kauffman 873 (MICH). NORTH CAROLINA. Avery Co.: 10 Jul 1978, Rohrer 2093 (NCU). Graham Co.: 12 Jun 1995 , Newell JKW3435 (NCU). Haywood Co.: 27 Jun 1958, Ramseur 4710 (NCU); 9 Jun 1975, Boufford 16262 (NCU). Jackson Co.: 31 Jul 1957, Ramseur 3706 (NCU). Mitchell Co.: n.d., K.M. s.n. (NCU). Swain Co.: 17 Jun 1957, Ramseur 3089 (NCU); 26 Jul 1957, Ramseur 3681 (NCU). Transylvania Co.: 9 Jun 1975, Boufford 16238 (NCU). Watauga Co.: 22 Jul 1940, Radford 1592 (NCU); 5 Aug 1957, Ramseur 3960 (NCU). Yancey Co.: 12 Jul 1921, Peattie 919 (NCU); 17 Aug 1949, Radford 4879 (NCU); 27 Jul 1956, Ramseur 1143 (NCU). PENNSYLVANIA. Bradford Co.: 15 Jun 1994, Naczi 4186 (MICH). Tioga Co.: 30 Jun 2004, Bissell 106 (MICH). TENNESSEE. Sevier Co.: 29 Jun 1969 , Rogers s.n. (NCU). VERMONT. Addison Co.: 28 Jul 1982, Zika 6301 (MICH). Chittenden Co.: 29 Jun 1981, Zika 7321 (MICH). East Dorset Co.: 12 Jun 1857, Ames s.n. (MICH). VIRGINIA. Grayson Co.: 17 Sep 1956, Ramseur 1875 (NCU). WEST VIRGINIA. Randolph Co.: 30 May 1991, Cusick 29608 (MICH). WISCONSIN. Iron Co.: 21 Sep 1974, Cochrane 6061 (MICH). Menominee Co.: 22 Aug 1974, Goff s.n. (NCU); 29 Jun 1997, DeJoode 1505 (MICH).

\section{Carex intumescens var. intumescens}

CANADA. MANITOBA. Division No. 1: 25 Jun 2003, Ford 0364 (MICH); 24 Jun 1996, Ford 9627 (MICH). Division No. 19: 11 Jul 1993, Punter 93/409 (MICH). NEW BRUNSWICK. Madawaska Co.: 20 Jul 1959, Cooley 6814 (NCU). NOVA SCOTIA. Colchester Co.: 10 Jul 1927, Prince \& Atwood 182-A (MICH). ONTARIO. Algoma District: 18 Jul 1931, Grassl 4376 (MICH); 27 Jul 1932, Hosie 803 (MICH); 21 Aug 1932, Grassl 4588 (MICH); 23 Aug 1932, Koelz 4572 (MICH). Chatham-Kent: 27 Jun 1979, Klinkenberg 0501 (MICH); 2 Jun 1986, Laberee KE86 3078 (MICH); 25 Jun 1987, Oldham \& Allen 7466 (MICH). Elgin Co.: 10 Jun 1986, Lamond 2158 (MICH); 3 Jul 1986, Bowles KE86 1398 (MICH); 29 Jul 1993, Oldham \& Vanderjeugd 15310 (MICH). Lambton Co.: 1 Jul 1987, Oldham 7513 (MICH). Manitoulin District: 18 Jul 1932, Koelz 4175 (MICH); 1 Jul 1936, Koelz 4441 (MICH). Middlesex Co.: 14 Sep 1993, Oldham E Vanderjeugd 15694 (MICH). Muskoka: 25 Jun 1972, Bobbette 3277 (MICH). Parry Sound District: 17 Sep 1936, Grassl 8019 (MICH). Renfrew Co.: 17 Jul 1961, Soper 9357 (NCU). 
Thunder Bay District: 25 Jul 1961, Voss \& Jeanne 10297 (MICH); 1 Aug 1961, Voss \& Jeanne 10488 (MICH); 10 Jul 1972, Hartley 1548 (MICH); 22 Jul 1977, Garton 19806 (MICH); 22 Jul 1982, Garton 21115 (MICH). QUÉBEC. Argenteuil: 22 Jun 1957, Jenkins 7449 (NCU). Rouyn-Noranda: 21 Jun 1952, Baldwin 2772 (MICH). Témiscouata: 2 Aug 1965, Gauthier 9569 (MICH). Vaudreuil-Soulanges: 15 Jun 1976, Newstrom 206 (NCU). U.S.A. ALABAMA. Baldwin co.: 0 May 1981, Wilhelm 8885 (USF). Choctaw Co.: 22 Jun 1966, Clark 3019 (NCU). Lee Co.: 29 Jun 1891, Earle s.n. (NCU). Mobile Co.: 21 May 1968, Lelong 4613 (NCU). Tuscaloosa Co.: 12 May 1948, Harper 4061 (NCU). ARKANSAS. Hempstead Co.: 7 May 1977, Redfearn 30439 (NCU); 17 May 1977, Redfearn 30786 (NCU). CONNECTICUT. Fairfield Co.: 11 Jul 1983, Mehrhoff 8296 (MICH). New Haven Co.: 4 Jul 1897, Eames s.n. (NCU). Oxford Co.: Jul 1902, Harger s.n. (MICH). Southington Co.: 12 Jun 1897, Andrews s.n. (MICH). Tolland Co.: 7 Sep 1991, Mehrhoff 15129 (MICH); 25 Jun 1992, Mehrhoff 15718 (MICH). Windham Co.: 27 Jun 1990, Mehrhoff 13477 (MICH). DELAWARE. Kent Co.: 13 Jun 2006, Longbottom 7519 (MICH). FLORIDA. Alachua co.: 6 Apr 1992, Orzell \& Bridges 19310 (USF). Duval Co.: 22 May 1896, Hiram 5664 (NCU). Franklin Co.: 3 Apr 1993, Orzell \& Bridges 21360 (USF). Gadsden Co.: 20 May 2006, Kral 97440 (TEX). Hamilton Co.: 28 Apr 1961, Cooley 8113 (USF). Hernando Co.: 12 Apr 1994, Orzell \& Bridges 22643 (USF). Marion Co.: 17 Apr 1993, Orzell \& Bridges 21600 (USF); 17 Apr 1993, Orzell \& Bridges 21604 (USF). Okaloosa Co.: 18 May 2016, Longbottom 24996 (USF). GEORGIA. Grady Co.: 9 Apr 2004, Kral 94903 (TEX). Jeff Davis Co.: 9 Jun 1967, Bozeman 9559 (NCU). Quitman Co.: 19 Apr 2004, Kral 95035 (TEX). ILLINOIS. Johnson Co.: 23 May 1990, Phillippe E Ulaszek 14069 (MICH). Porter Co.: 8 Sep 1961, Laskowski 321 (MICH). KENTUCKY. Laurel Co.: 15 Jun 1998, Naczi 7376 (MICH). McCreary Co.: 3 Jul 1939, McFarland 3504 (MICH). LOUISIANA. Bienville Parish: 14 May 1977, Allen 7900 (NCU). Grant Parish: 13 May 1977, Allen 7800 (USF); 5 May 1998, Hyatt 8091 (TEX). Ouachita Parish: 25 Apr 1967, Thomas 2554 (NCU); 30 Apr 1999, Thomas 159192 (TEX). St. Tammany Parish: 19 Jun 1967, Thieret 26966 (TEX); 16 May 1994, Slaughter 4888 (TEX); 11 May 2004, Ferguson 1461 (TEX). Washington Parish: 13 May 1972, Rogers 8040 (NCU). Winn Parish: 17 May 1993, Jones 10083 (USF). MAINE. Aroostook Co.: 13 Jul 1983, Gawler 274 (MICH). Franklin Co.: 12 Jun 1906, Chase 3417 (MICH); 12 Jul 1906, Chase 3417 (MICH). Piscataquis Co.: 1 Aug 1917, Grover s.n. (MICH). Washington Co.: 3 Jul 1994, Reznicek 9917 (MICH). MARYLAND. Kent Co.: 13 Jun 2006, Longbottom 7539 (MICH). Lexington Park Co.: 7 Jul 1994, Davis 1580, (MICH). Montgomery Co.: 12 Jun 1837, Kearney s.n. (NCU). Wicomico Co.: 18 Jun 2006, Longbottom 7551 (MICH). MASSACHUSETTS. Hampshire Co.: 11 Aug 1949, Cooke s.n. (NCU). Michigan. Arenac Co.: 20 Jun 1961, Sharp s.n. (MICH). Chippewa Co.: 6 Aug 1957, Voss 5172 (MICH). Clinton Co.: 19 Jun 1952, Parmelee 128 (MICH). Crawford Co.: Sep 1888, Hicks s.n. (MICH). Emmet Co.: 14 Jul 1935, Ehlers 5847 (MICH); 26 Jun 1953, Wood 8088 (MICH). Houghton Co.: 25 Jul 1955, Hyypio 488 (MICH). Kalamazoo Co.: 3 Sep 1929, Ehlers 4351 (MICH). Kent Co.: 10 Jun 1894, Cole s.n., (MICH). Keweenaw Co.: 8 Aug 1930, McFarlin 2387 (MICH); 17 Aug 1959, Long 5326 (MICH). Midland Co.: 6 Jul 1927, R.R.D. 5011 (NCU); 25 Jul 1931, R.R.M.T. 7314 (NCU); 1 Jul 1935, Dreisbach 847 (MICH). Presque Isle Co.: 11 Jul 1961, Hubbard 67 (MICH). Tuscola Co.: 19 Jun 1958, Voss 6749 (MICH). MINNESOTA. Cook Co.: 25 Jul 1975, Ownbey 5054 (NCU). Lake Co.: 16 Jul 1961, Voss \& Jeanne 10060 (MICH). Saint Louis Co.: 13 Aug 1987, Castaner 9944 (MICH); 13 Aug 1987, Castaner 9966 (MICH); 24 Aug 1994 , Stalter 87 (MICH). Sweetwater Co.: 8 Jul 1986, McNeilus s.n. (MICH). MISSISSIPPI. Covington Co.: 11 Jul 1950, Webster \& Wilbur 3329 (USF). Forrest Co.: 4 May 1971, Rogers 6212 (NCU). Jackson Co.: 3 Aug 1952, Ray 3086 (USF); 18 Apr 1954, Demaree 3490 (USF). Lamar Co.: 14 May 1969, Rogers 1159-B (NCU). Monroe Co.: 12 Jun 1956, Ray 6277 (USF). Scott Co.: 17 June 1969, Jones 16668 (NCU). Tishomingo Co.: 13 Jun 1956, Ray 6334 (USF). NEW HAMPSHIRE. Cheshire Co.: 20 Aug 1974, Boufford 15577 (NCU). NEWJERSEY. [no location data], s.d., Willis s.n. (MICH). NEW YORK. Orange Co.: 1 Jul 1936, Raup 7436 (MICH). OHIO. Cuyahoga Co.: Jun 1897, Watson s.n. (MICH). Harrison Co.: 21 Jun 1983, Cusick 22596 (MICH). Lorain Co.: 18 Jul 1991, Bissell 163 (MICH). Medina Co.: 24 Jun 1986, Cusick 25415 (MICH). Tacoma Co.: 20 Jun 1897, Pieters s.n. (MICH). Williams Co.: 31 Aug 2000, McCormac 6958 (MICH). NORTH CAROLINA. Alamance Co.: 27 May 1960, Radford 43051 (NCU). Alleghany Co.: 26 Jun 2005, Poindexter 05-887 (NCU). Bertie Co.: 29 May 1958, Ahles 41339A (NCU). Buncombe Co.: 2 Jul 1897, Biltmore Herbarium 1793a (NCU); 28 Jun 1958, Ramseur 4826 (NCU). Burke Co.: 11 Jun 1957 , Bell 8766 (NCU). Caldwell Co.: 4 Aug 1956, Radford 15107 (NCU). Cherokee Co.: 27 May 1956, Radford 11669 (NCU). Craven Co.: 17 May 1976, Snyder 831 (NCU). Cumberland Co.: 4 May 1957, Ahles 24314 (NCU). Davidson Co.: 16 Jun 1956, Radford 12845 (NCU). Greene Co.: 11 Jul 1958, Radford 36449 (NCU). Guilford Co.: 3 Jun 1958, Bell 12451 (NCU). Haywood Co.:14 Jun 1974, Boufford 14291 (NCU). Henderson Co.: 5 Jun 1953, Radford 7105 (NCU); 9 Jul 1975, Boufford 17245 (NCU). Hertford Co.: 30 May 1958, Ahles 41645 (NCU). Jackson Co.: 24 Jun 1956, Ramseur 303 (NCU); 8 Jan 1957, Ramseur 3904 (NCU). Johnston Co.: 19 Jun 1957, Radford 25320 (NCU). Martin Co.: 16 Jun 1958, Radford 35399 (NCU). McDowell Co.: 20 Jun 1977, Rothrock 1227 (NCU). Mitchell Co.: 6 Aug 1956, Ramseur 1239 (NCU); 25 Jul 1975, Wood 17717 (NCU). Montgomery Co.: 24 Jun 1956, Radford 13235 (NCU); 18 May 1970, Wells 2956 (NCU). Northampton Co.: 31 May 1958, Ahles 41916 (NCU). Onslow Co.: 14 Jun 1957, Ahles 28289 (NCU). Pamlico Co.: 13 Jun 1949, Radford 4455 (NCU). Pender Co.: 4 May 1940, Radford 229 (NCU). Pitt Co.: 14 Jul 1958, Radford 34917 (NCU). Polk Co.: 18 May 2005, Franklin 6312 (NCU). Randolph Co.: 27 May 1958, Bell 12194 (NCU); 19 May 1976, Wickland 984 (NCU). Rockingham Co.: 8 Jun 1961, Radford 43826 (NCU). Rowan Co.: 29 Apr 1957, Horton 958 (NCU). Sampson Co.: 5 May 1957, Ahles 24680 (NCU). Stokes Co.: 1 Jun 1940, Radford 471 (NCU). Surry Co.: 23 Jun 1956, Radford 13119 (NCU). Transylvania Co.: 8 Aug 1957, Freeman 57415 (NCU). Wake Co.: 22 May 1960, Radford 42939 (NCU). Wayne Co.: 3 May 1957, Radford 22035 (NCU). Yancey Co.: 8 Jul 1982, McLeod 1601 (NCU). PENNSYLVANIA. Clinton Co.: 4 Jul 1995, Naczi 4888 (MICH). Forest Co.: 7 Jul 1993, Zanol 1713 (MICH). Lehigh Co.: 8 Aug 1915, Pretz 7743 (MICH). Mercer Co.: 30 Jun 1955, Wahl 16211 (NCU); 11 Jul 1984, Cusick 23653 (MICH). Union Co.: 6 Jul 2000, Hill 32595 (MICH). RHODE ISLAND. Washington Co.: 5 Jul 2002, Sanders 25334 (MICH). SOUTH CAROLINA. Allendale Co.: 13 May 1956, Bell 2689 (NCU). Bamberg Co.: 26 May 1957, Ahles 26124 (NCU). Barnwell Co.: 12 Jun 1987, Horn 1881 (NCU). Beaufort Co.: 10 May 1956, Ahles 123401 (NCU); 10 May 1956, Bell 2432 (NCU). Kershaw Co.: 3 Jun 1957, Radford 23525 (NCU). Marlboro Co.: 10 Jun 1956, Radford 12619 (NCU). Orangeburg Co.: 18 May 1957, Ahles 25212 (NCU). TENNESSEE. Johnson Co.: 17 Jun 1934, JKU \& AJS s.n. (NCU). Putnam Co.: 9 Jul 1946, Radford 2595 (NCU). TEXAS. Cass Co.: 17 May 1970, Correll 38690 (TEX). Galveston Co.: 8 Apr 1975, Waller 3506 (TEX). Hardin Co.: 19 May 2004, Sanders 6582 (TEX). Jefferson Co.: 6 Apr 1944 , Crockett 6842 
(TEX). Montgomery Co.: 18 May 2004, Sanders 565 (TEX). Sabine Co.: 27 Apr 1963, Ewan 21299 (TEX). Shelby Co.: 5 Jul 1956, Correll 15350 (TEX). Tyler Co.: 28 Apr 2000, Carr 18756 (NCU). Wharton Co.: 17 Apr 939, Tharp 43273 (TEX). VirginiA. Charles City Co.: 20 Jun 1969, Ware 2369 (NCU). Charlotte Co.: 1 Aug 1967, Ramsey s.n. (NCU). Giles Co.: 11 Jul 1960, Kral 10733 (NCU); 21 Jun 1971, Musselman 4317 (NCU). Montgomery Co.: 25 Jun 1974, Uttal 10469 (NCU). New Kent Co.: 2 Jul 1974, Soltis 246 (NCU). Rockbridge Co.: 20 Jul 1967, Gupton 3383 (NCU). Southampton Co.: 12 Jul 1972, Harvill 25824 (NCU). Suffolk City Co.: 14 May 1974, Musselman 4702 (NCU). VERMONT. Orange Co.: 3 Jul 1991, Boufford $\&$ Wood 25626 (MICH). WISCONSIN. Adams Co.: 1 Sep 1959, Hartley s.n. (NCU). Chippewa Co.: 13 Jun 1963, Henrickson 1344 (MICH). Iron Co.: 21 Sep 1974, Cochrane 6081 (MICH). Jackson Co.: 27 Jul 1989, McNeilus 89-533 (MICH); 13 Jun 1999, Reznicek 10872 (MICH). Juneau Co.: 1 Jun 1987, McNeilus 87-855 (MICH). Wood Co.: 7 Jun 1991, McNeilus 91-490 (MICH). WEST VIRGINIA. Pocahontas Co.: 27 Jul 1994, Nelson 15878 (MICH).

\section{EUPHORBIACEAE}

Euphorbia: A new species of Euphorbia subgenus Chamaesyce from southern Florida, and a new name. Primary authors: Keith A. Bradley and Jimi Sadle

Reevaluation of Euphorbia porteriana in southern Florida rockland ecosystems indicates that three species should be recognized. Euphorbia hammeri is described as a new species endemic to the Everglades region of the southern Florida mainland. Its geographic isolation and rarity resulted in it being overlooked. It is partly sympatric with Euphorbia porteriana, which is endemic to Miami-Dade County. A new name is required for the Florida Keys endemic Chamaesyce scoparia Small, recognized now as Euphorbia ogdenii.

Florida, particularly southern peninsular Florida and the Florida Keys, is a hotspot of endemism in Euphorbia, subgenus Chamaesyce, sect. Anisophyllum, subsect. Hypericifoliae. Seven taxa from sect. Anisophyllum are endemic to Florida, six of which are entirely restricted to the extreme southern portion of the state (Berry et al. 2016; Weakley 2020; Wunderlin et al. 2021). Among the endemics, a E. porteriana (Small) Oudejans species complex is distinguished from similar species in the area by having glabrous capsules, cyathia that are solitary in the leaf axils, mostly entire leaf margins, and inconspicuous united stipules. Euphorbia porteriana is morphologically most similar to the endemic E. garberi Engelm. ex Chapm., a Federally Threatened species. Herndon (1993) clarified the distinction of E. garberi from E. porteriana (both as Chamaesyce), which were confused by Burch $(1965,1966)$. Herndon treated all specimens that have uniformly pubescent capsules and usually pubescent foliage as E. garberi. This broadened concept of E. garberi includes C. adicioides Small, C. brachypoda Small, C. mosieri Small, and C. keyensis Small (none transferred to Euphorbia), which we follow, as do others (Wunderlin \& Hansen 2011; Berry et al. 2016; Weakley 2020). Yang and Berry (2011) placed E. porteriana and E. garberi in a "Euphorbia serpens species complex" and hypothesized that the species, as well as E. blodgettii, are derived from E. serpens (Kunth) Small, and that E. porteriana and E. garberi are derived from hybridization events involving E. serpens and several other taxa, possibly including E. dioeca and E. deltoidea.

Small (1903) described C. porteriana based on a specimen collected in Miami, Miami-Dade County (Garber s.n., NY) and later considered it to be endemic to the county (Small 1933). In addition, Small (1913) described C. scoparia Small from a specimen collected on Big Pine Key, Monroe County (Small 3819, NY) and considered that species to be endemic to the Florida Keys in the county (Small 1933). In a Caribbean-wide treatment of Chamaesyce, Burch (1965) considered C. scoparia to be a variety of C. porteriana, endemic to the Florida Keys, and he later published the combination C. porteriana var. scoparia (Small) Burch (Burch 1966). Burch $(1965,1966)$ considered C. porteriana var. porteriana to be in both Miami-Dade County and the Florida Keys but his concept of var. porteriana included pubescent plants that represent C. garberi (Herndon 1993). Herndon treated all glabrous plants in both Miami-Dade County and the Florida Keys as one species, C. porteriana, and considered C. scoparia, with narrower leaves, to be a weakly differentiated form. This treatment has been followed by Wunderlin andd Hansen (2011), Berry et al. (2016), and Weakley (2020).

In 1978, a specimen of Chamaesyce (Black \& Black 203, FNPS, FTG) was collected in the Big Cypress National Preserve in an area known as the Lostman's Pines region, in mainland Monroe County (Avery \& Loope 1980). A subsequent collection was made in 1979 (Rochefort 100, FNPS). The specimens were labeled as C. porteriana Small and as C. porteriana var. scoparia (Small) Burch by the collectors. These represent the first collections of any C. porteriana s.l. from mainland Monroe County or elsewhere in southwest Florida. The first 
author examined one specimen (Black \& Black 203, FTG) in the early 1990s and recognized that it differed from C. porteriana s.l. in having extremely long, narrow leaves as well as deep red cyathia, capsules, and stems. The long narrow leaves resembled some specimens of C. porteriana from the Florida Keys, but far exceeded the length and proportions of any other specimens. The late George N. Avery described observing this taxon in his unpublished field notes from the same area in 1981 (archived at Fairchild Tropical Botanic Garden, Coral Gables, Florida). No other documentation of C. porteriana s.l. from this region has been found by the authors.

In the early 2000s, during field work in the Lostman's Pines region in the vicinity of the original collections, the taxon was rediscovered at several stations separated by as much as $7 \mathrm{~km}$. In 2004, the second author estimated an overall population of 1,001-10,000 individuals from Lostman's Pines. All individuals showed the distinctive leaf dimensions and red pigmentation. In 2017, the second author discovered a population of Chamaesyce with the same characteristics in the Long Pine Key region of Everglades National Park in MiamiDade County, approximately $50 \mathrm{~km}$ southeast of the Lostman's Pines populations. An estimated 1,000 plants were observed in a 4-ha area. This population was growing within $100 \mathrm{~m}$ of C. porteriana with typical morphology and within the same pine rockland habitat type, but the two taxa were not found growing intermixed.

The distinctive features of this taxon, in both field observations and examination of specimens and the consistency of these characters between disjunct occurrences, indicated that the taxon was probably undescribed and related to C. porteriana and C. scoparia. Long-term field study of C. porteriana s.l. in Miami-Dade County and the Florida Keys indicated that the difference between mainland and Florida Keys populations should also be reevaluated to determine the most appropriate treatment of those taxa as well.

There has been a trend to treat Chamaesyce in a broadly circumscribed Euphorbia based on phylogenetic data (Steinmann \& Porter 2002; Bruyns et al. 2006; Yang \& Berry 2011; Yang et al. 2012; Berry et al. 2016). Some authors follow the broad treatment with reservations (Weakley 2020). In this work we adopt the broad concept of Euphorbia.

All specimens of E. porteriana s.l. were borrowed from FNPS, FTG, NY, and USF, including the type specimens. Ninety-six specimens were studied, including 44 of E. porteriana, 43 of E. ogdenii, and nine of E. hammeri. Length and width were measured from three representative mid-stem leaves on each sheet. Gland and gland appendage length (lateral dimension) and width (radial dimension) were also measured. Overall leaf shape, including base and apex shape, was recorded, as was the number of veins (midrib and secondary veins) visible in each leaf. The color of leaf veins, stems, glands, gland appendages, and capsule was recorded. Pedicels of mature capsules were characterized qualitatively as slender or stout. Measurements were also made of pickled specimens of E. porteriana and E. hammeri. Quantitative measurements show consistent differences in leaf shape and size between the three taxa (Fig. 5, Table 2). The three taxa were also found to be consistently separable by several other qualitative characters (Table 2).

Based on quantitative and qualitative characters we conclude that this complex consists of three taxa best treated as species: E. porteriana is endemic to Miami-Dade County, E. ogdenii (= C. scoparia) is endemic to the Florida Keys (requiring a new name if treated, as here, in Euphorbia), and E. hammeri is a previously undescribed species that we circumscribe here. We name this species in honor of our friend Roger L. Hammer of Homestead, Florida, naturalist, author, and photographer, who has spent his life sharing his love of natural Florida with others.

Euphorbia hammeri K.A. Bradley \& Sadle, sp. nov. (Figs. 6, 7, 8). Type: U.S.A. FloridA. Monroe Co.: Big Cypress National Preserve. Around bases of cypress trees in a pine-cypress area, 24 May 1978, D. E S. Black 203 (HOLOTYPE: FNPS!, Fig. 6; IsotyPE: FTG!).

Diagnosis.-Differing from E. porteriana and E. ogdenii by its narrowly lanceolate to narrowly elliptic (vs. ovate to narrowly elliptic) leaves that are generally 3-6 (vs. 1.0-2.5) times as long as wide, with 1 vein (vs. 1-3 veins), widely spaced on the stem (vs. narrowly spaced), red to deep red pigmentation throughout the plant except for deep green adaxial leaf surfaces (vs. green to pink); slender elongated peduncles (vs. stout, short); and by large (vs. small), deep purple to purplish black (vs. green to pink) glands, with radially narrow (vs. wide) appendages that border the gland. 


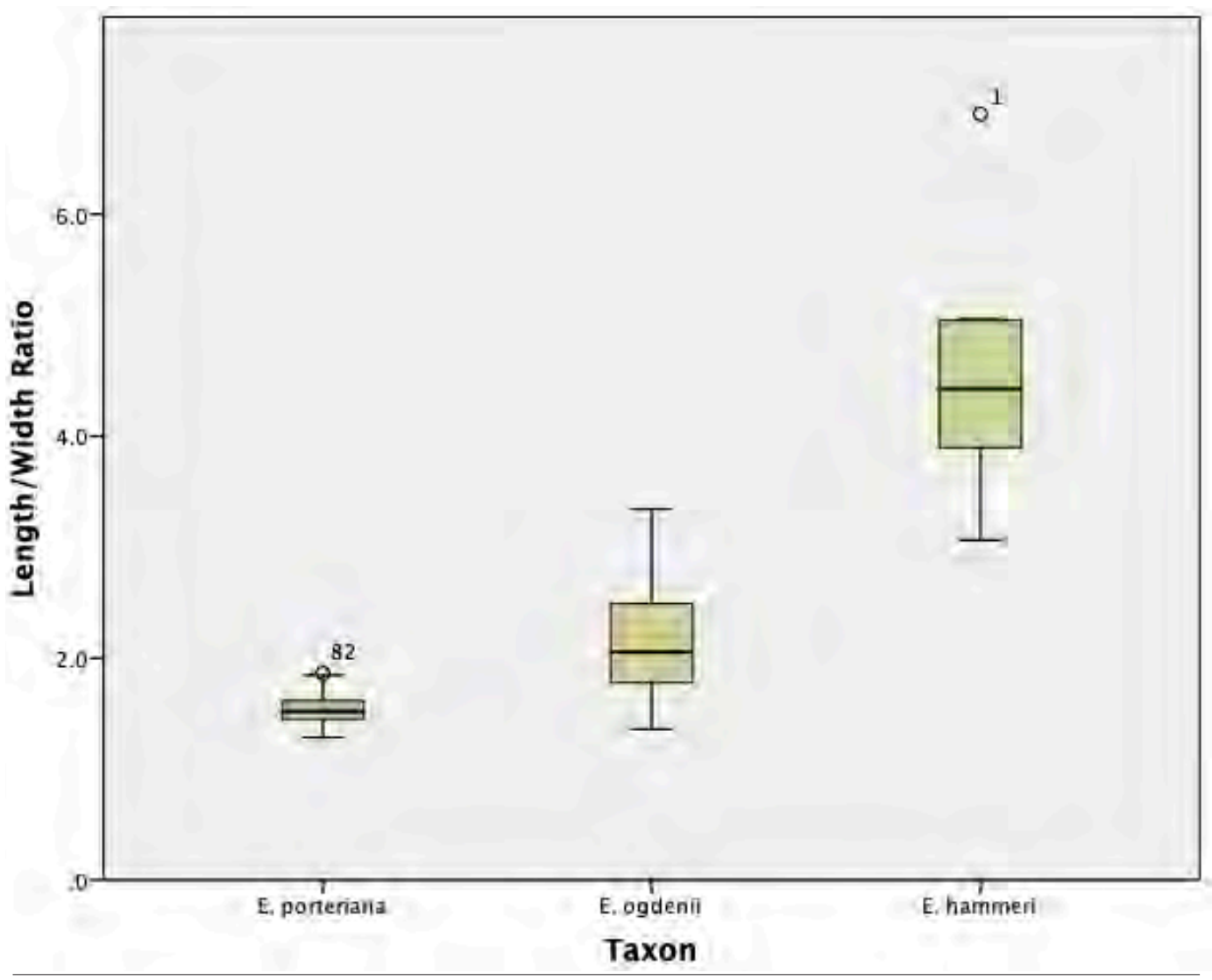

\section{Fig. 5. Leaf length-to-width ratios of Euphorbia taxa.}

Description.-Herbs, perennial, with thickened taproot, $5 \mathrm{~mm}$ diam. Stems erect to ascending, sometimes slightly woody at base, reddish to red throughout, not mat-forming, 15-60 cm, glabrous. Leaves opposite, generally held perpendicular to stem, widely spaced on stem, 2-4 cm apart; stipules usually distinct, occasionally connate basally, triangular, entire or 2-3 parted, $0.4-0.6 \mathrm{~mm}$, glabrous, petiole $0.5-2.0 \mathrm{~mm}$, glabrous; blades sometimes slightly falcate, narrowly elliptic or linear-elliptic, 4.9-12.5 × 1.1-2.5 mm, (2.2-)3-6(-8.25) times longer than wide, base asymmetric, rounded, margins entire, apex acute, sometimes mucronate, abaxially purple or red, adaxially green, glabrous; 1-veined from base, vein light to deep red. Cyathia solitary at distal nodes; peduncle slender, usually longer than cyathial cup, 1.0-1.5 mm. Involucres turbinate to campanulate, $0.7-1 \times 0.8-1 \mathrm{~mm}$, usually glabrous, rarely very sparsely short pubescent; glands 4 , dark red to purplish black, slightly concave, narrowly elliptic-oblong, 0.5-0.9 × 1.0-1.6 mm; appendages dark red, bordering and with radial dimension less than that of the gland, $(0-) 0.1-0.4 \times 1.2-1.5 \mathrm{~mm}$, distal margin entire or slightly crenulate. Staminate flowers $8-14$, anthers orange. Pistillate flowers: ovary glabrous, subtended by triangular calyxlike structure; styles $0.5-0.6 \mathrm{~mm}$, bifid 1/2-2/3 length. Capsules deep red, broadly ovoid, 1-1.5 × 1.7-2.1 mm, glabrous; columella 1-1.4 mm. Seeds reddish brown, ovoid, 4-angled in cross section, $0.7-1 \times 0.6-0.7 \mathrm{~mm}$, smooth or obscurely wrinkled.

Additional specimens examined. FLORIDA. Monroe Co.: found in pineland S of Pace's Dike which burned 3 months ago, T55S, R33E, Sec. 35, 4 Apr 1979, Rochefort 100 (FNPS); Big Cypress National Preserve, Lostman's Pines area, located approx. 6.12 km S of Loop Road (CR94), $17.34 \mathrm{~km}$ W of the Miami-Dade county line, S of Charlie Jumper Hammock, common in wet pine rockland, 8 Sep 2002, Woodmansee E Sadle 958 (FNPS); Big Cypress National Preserve, S of Loop Road, in pine flatwoods, 8 Nov 2002, Bradley 2441 (FNPS); Big Cypress National 
TABLE 2. Characters to separate Euphorbia hammeri, E. porteriana, and E. ogdenii.

\begin{tabular}{|c|c|c|c|}
\hline Character & E. hammeri & E. porteriana & E. ogdenii \\
\hline Leaf length and width (mm) & $4.9-12.5 \times 1.1-1.7$ & $3.0-4.5 \times 1.9-4.9$ & $2.3-6.6 \times 1.0-3.8$ \\
\hline Leaf length mean $(\mathrm{mm})$ & 7.2 & 4.5 & 4.2 \\
\hline $\begin{array}{l}\text { Leaf length/width ratio range } \\
\quad \text { (rare outliers in parentheses) }\end{array}$ & $(2.2-) 3.0-6.0(-8.3)$ & $1.0-1.7(-2.0)$ & $(1.0-) 1.8-2.5(-3.5)$ \\
\hline Leaf length/width ratio mean & 4.5 & 1.5 & 2.1 \\
\hline Visible leaf veins & 1 & 3 & $1-3$ \\
\hline Leaf vein color & red to green & green & green to red \\
\hline Leaf shape & $\begin{array}{l}\text { narrowly lanceolate to narrowly } \\
\text { elliptic }\end{array}$ & ovate to oval & $\begin{array}{l}\text { narrowly elliptic to narrowly } \\
\text { ovate }\end{array}$ \\
\hline Leaf base & rounded & cordate to rounded & rounded \\
\hline Leaf apex & acute & obtuse & acute \\
\hline Gland color & deep red to purplish black & green to yellowish brown & green \\
\hline Gland appendage color & deep red & white or pink & white or pink \\
\hline Gland length and width $(\mathrm{mm})$ & $1.0-1.6 \times 0.5-0.9$ & $0.6-1.0 \times 0.3-0.5$ & $0.4-0.6 \times 0.2-0.3$ \\
\hline Gland appendage & $\begin{array}{l}\text { narrowly elliptic, radial } \\
\text { dimension smaller than gland, } \\
\text { mostly entire }\end{array}$ & $\begin{array}{l}\text { flabellate, radial dimension } \\
\text { equal to or wider than gland, } \\
\text { entire to crenulate }\end{array}$ & $\begin{array}{l}\text { flabellate, radial dimension } \\
\text { equal to or wider than } \\
\text { gland, entire to crenulate }\end{array}$ \\
\hline Capsule color & dark red & green & green or light red \\
\hline Pedicel & slender & stout & stout \\
\hline Upper stem & light pink to dark red & green to light red & green to light red \\
\hline Range (counties) & Mainland (Miami-Dade, Monroe) & Mainland (Miami-Dade) & Florida Keys (Monroe) \\
\hline
\end{tabular}

Preserve, in Pinus-Sabal savanna with some exposed limestone S of Loop Road, 23 Oct 2004, Sadle E Hodges 242 (FNPS). Miami-Dade Co.: Everglades National Park, in pine rockland with Cladium jamaicensis, Schizachyrium rhizomatum, Serenoa repens, Sabal palmetto, Muhlenbergia capillaris, Chamaesyce conferta, Morinda royoc, Chiococca parvifolia, and Cassytha filiformis, 2 May 2017, Sadle 744 (FNPS); Everglades National Park, in marl prairie/pine rockland ecotone and adjacent marl prairie, southern edge of Pine Block B, plants erect, stems, cyathia and capsules red, leaves green, ca. 1,000 individuals, 30 May 2017, Sadle 748 (FNPS).

Euphorbia hammeri occurs in open understory, fire-dependent, and seasonally flooded habitats dominated by Pinus densa (Little \& K.W. Dorman) Silba in the southern tip of the Florida peninsula. It is known from two geographically isolated areas, both located entirely within lands managed by the National Park Service and separated from one another by the Shark River drainage of the southern Everglades. Lostman's Pines is a loosely defined region south of Florida State Road 94 (Loop Road) in southern Big Cypress National Preserve. The area is characterized by thin marl and sand soils overlaying limestone bedrock. Subtle topographic changes and associated hydrologic conditions result in island-like formations of pine forest intermixed with graminoid prairies, Taxodium ascendens Brongn. forests and savannas and rockland hammocks dominated by temperate and tropical hardwood trees. In this area, E. hammeri occurs in association with mesic to moist $P$. densa savannas with some exposed limestone outcrops. Long Pine Key in Everglades National Park is located at the southwestern end of the Miami Rock Ridge. This region includes a series of elevated Miami Oolite limestone formations overlain with thin marl soils that support pine rockland and rockland hammock habitats bisected by marl prairies that occur in lower elevation, north-to-south drainages. Within Long Pine Key, E. hammeri occurs in a small area of pine rockland and associated marl prairie. The occurrence is immediately north of a previously farmed area where both habitat types are no longer present. The distribution of E. hammeri is similar to that of two other southern Florida endemic plants, Digitaria pauciflora Hitch. (Poaceae), and Sideroxylon reclinatum Michx. ssp. austrofloridense (Whetstone) Kartesz \& Gandhi (Sapotaceae). Both species are also restricted to pineland and marl prairie habitats in Long Pine Key and southern Big Cypress National Preserve.

Euphorbia hammeri is locally frequent but has a very limited known range, which makes it disproportionately vulnerable to ecological changes, so it should be considered a species of conservation concern. We recommend for it a conservation rank of G2 "Imperiled" (NatureServe 2020). Fortunately, the entire distribution of E. hammeri is located within lands managed by the National Park Service and is largely protected from 


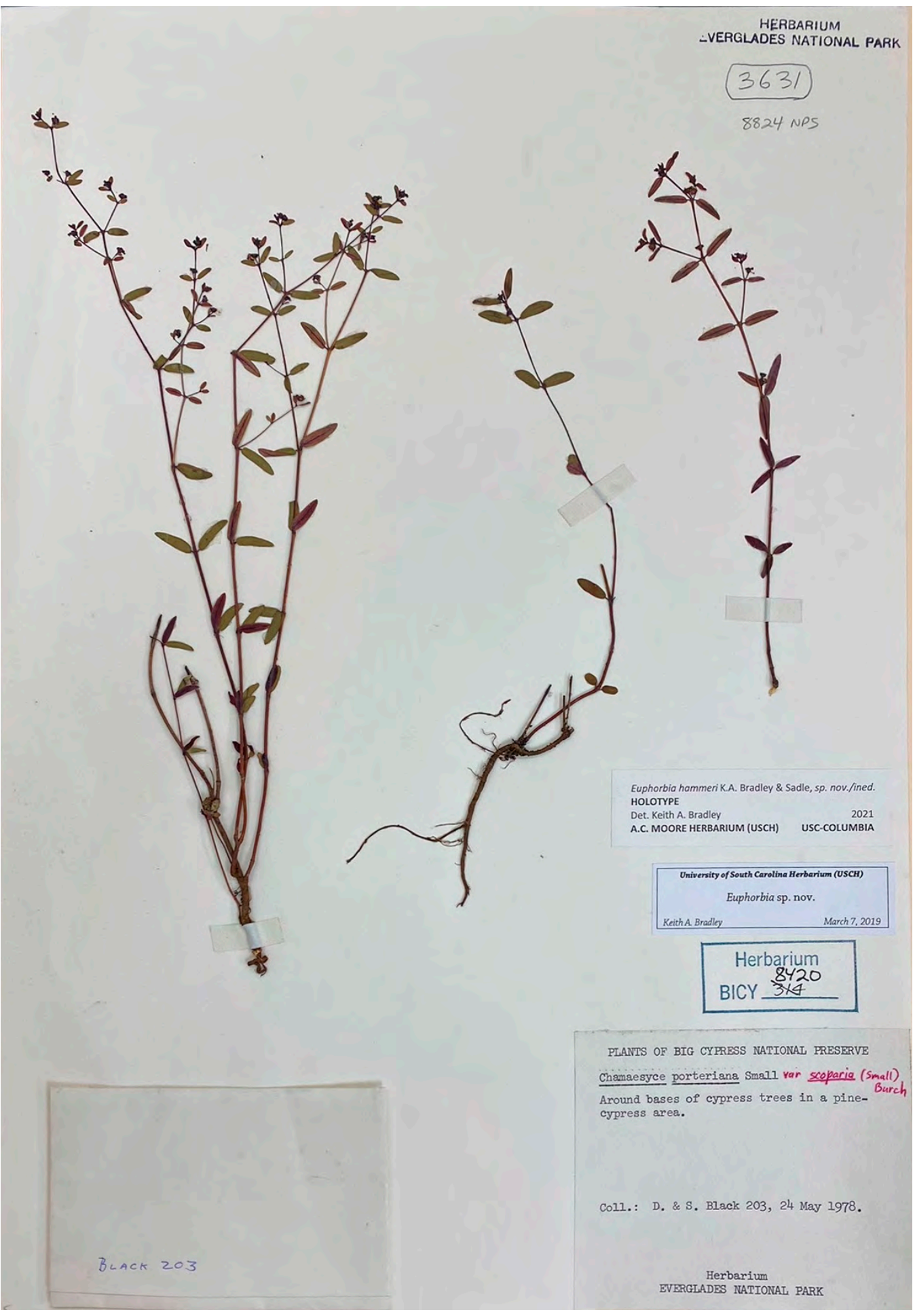




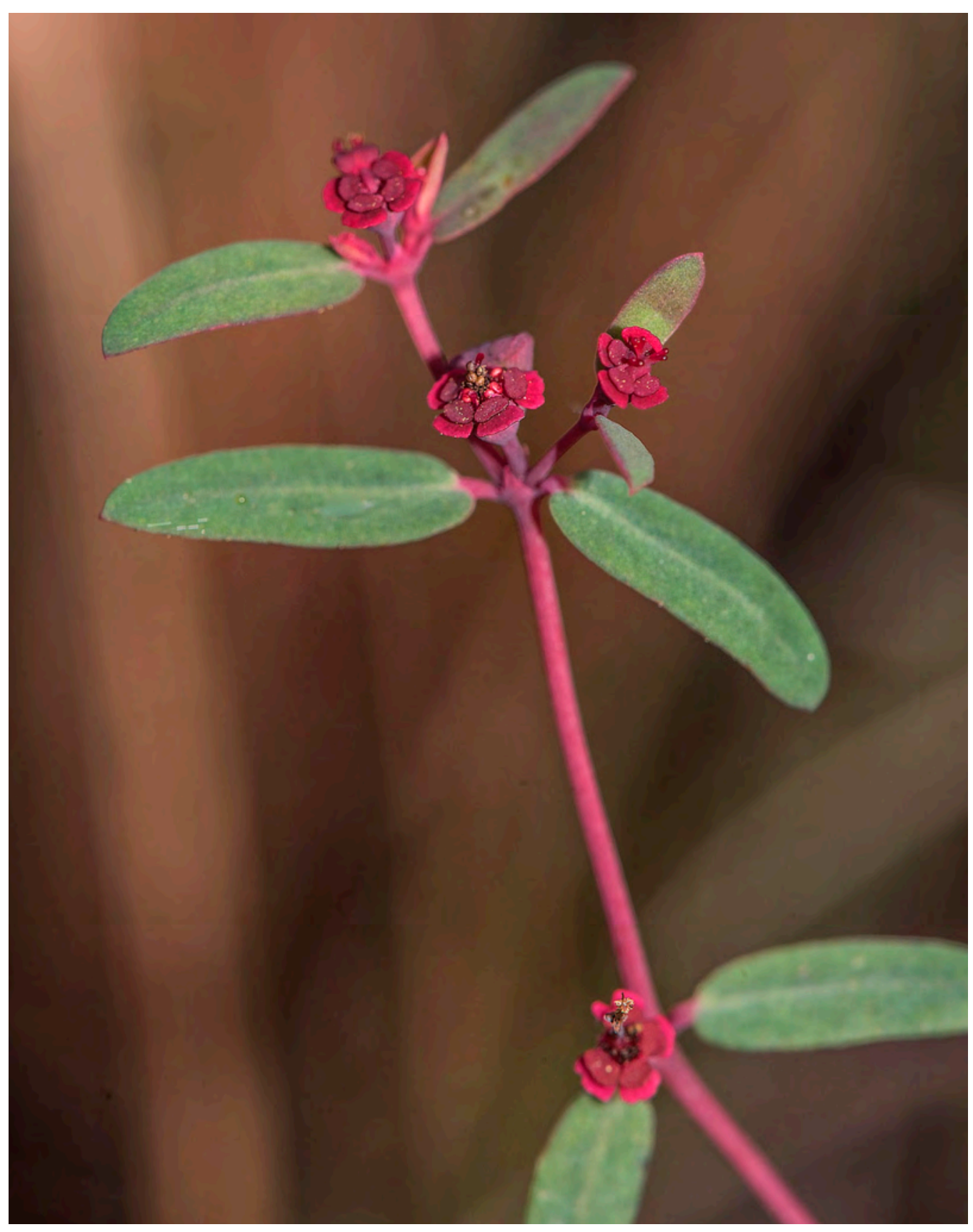

FiG. 7. Euphorbia hammeri. Miami-Dade County, Everglades National Park (photo by Roger L. Hammer). 


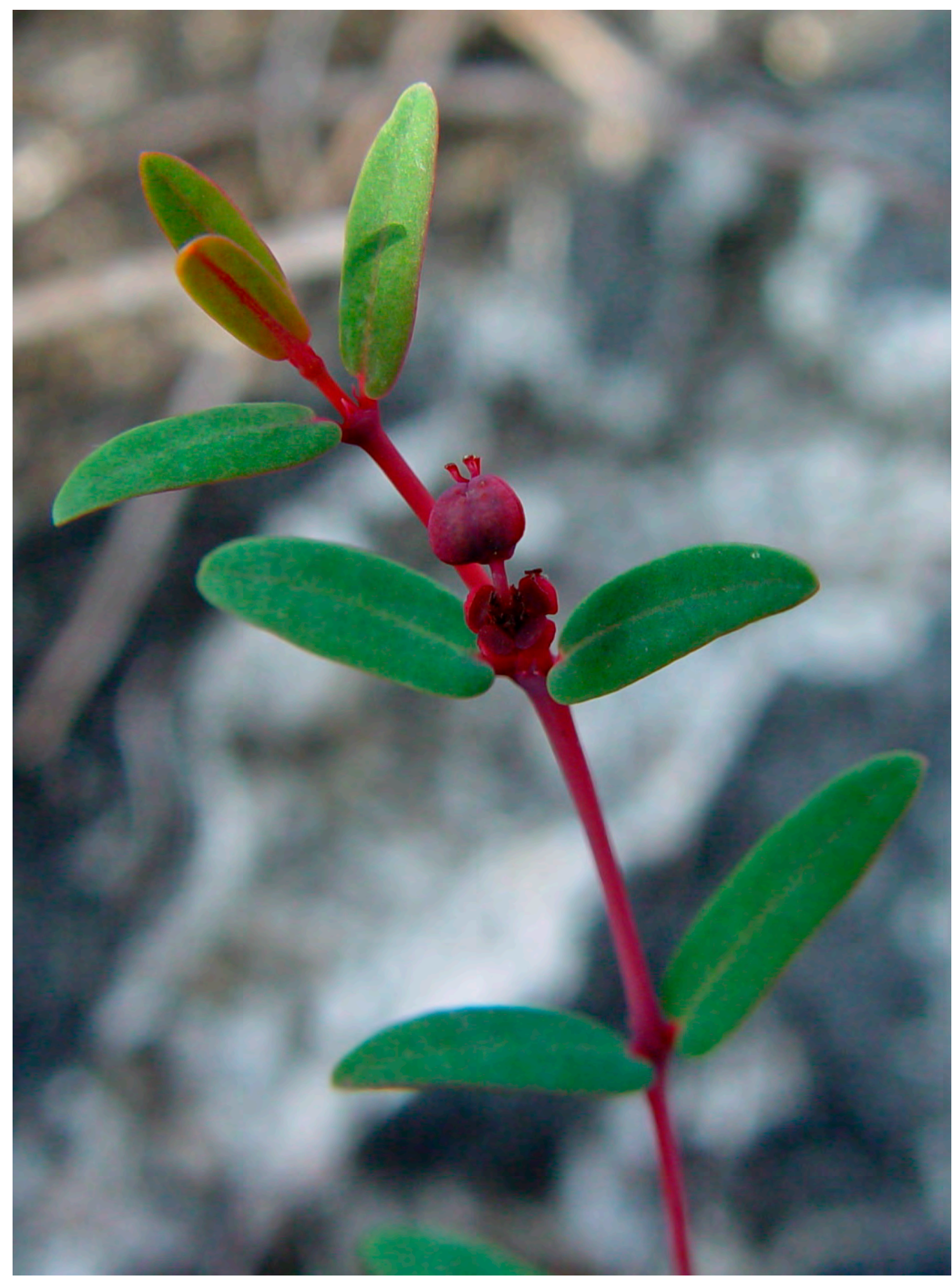

Fig. 8. Euphorbia hammeri. Monroe County, Big Cypress National Preserve (photo by Keith A. Bradley). 
development and land-use changes. Localized impacts to plants and suitable habitat from administrative and recreational off-road vehicle use are also likely affecting the occurrence in the Lostman's Pines region of Big Cypress National Preserve. Potential range-wide threats to the species include non-native plant infestations, failure to maintain natural fire patterns, and sea level rise. Both park service units have long-standing and active fire management and exotic plant control programs, which currently minimizes these threats. Additionally, changes in hydrologic conditions associated with landscape-scale restoration projects and sea level rise have the potential to alter hydroperiods in areas where E. hammeri occurs, which may represent a significant threat to the long-term survival of the species.

We find that Chamaesyce scoparia plants in the Florida Keys differ sufficiently from related taxa to be recognized at species rank, following Small's original concept, circumscription, and rank (Small 1913, 1933). This species is geographically isolated from E. hammeri and E. porteriana and readily distinguished from them by several characters. Leaf shape is most similar to E. hammeri but C. scoparia leaves are consistently both shorter and with lower length-to-width ratios. Plants are green to often suffused with light pink but lack the deep red coloration of E. hammeri. The glands are much smaller than those of E. hammeri and have usually flabellate appendages that are wider than the glands in the radial dimension. Chamaesyce scoparia is readily distinguished from E. porteriana (Figs. 9, 10) by its narrowly elliptic to narrowly ovate leaves, rounded instead of cordate leaf bases, and smaller glands (Table 2). The species is widespread in the upper and lower Florida Keys from at least Plantation Key to Key West. It is always associated with either Miami Oolite or Key Largo Limestone and can be found in pine rockland, coastal rock barrens, and canopy gaps or edges of rockland hammocks. The species is rare and should be considered globally imperiled.

After being named at species rank, Chamaesyce scoparia has been treated at varietal rank as C. porteriana Small var. scoparia (Small) D.G. Burch and as E. porteriana (Small) Oudejans var. scoparia (Small) Oudejans. In order to treat this taxon at the appropriate species rank in Euphorbia, however, a new name is required because a new combination at species rank based on the epithet 'scoparia' is blocked by an earlier homonym, Euphorbia scoparia N.E. Br. 1911, a plant of Africa. We name it after the late John C. Ogden (1938-2012), ornithologist, Everglades restoration scientist, our friend, and next-door neighbor and close friend of Roger L. Hammer.

Euphorbia ogdenii K.A. Bradley \& Sadle, nom. nov. (Figs. 11, 12). Replaced name: Chamaesyce scoparia Small, Flora of the Florida Keys 81, 155. 1913 [non Euphorbia scoparia N.E. Br., Flora of Tropical Africa 6(1):557. 1911]. Type: U.S.A. FloRidA: Monroe Co.: Big Pine Key, Small 3819 (NY!, Fig. 11).

Synonyms. Chamaesyce scoparia Small; C. porteriana Small var. scoparia (Small) Burch; Euphorbia porteriana (Small) Oudejans var. scoparia (Small) Oudejans.

The narrow distributions and imperiled habitats of these south Florida endemic Euphorbia species emphasize the importance of taxonomic assessment. We assess E. ogdenii as being a G1 (= Critically Imperiled) species, E. hammeri a G2 (= Imperiled) species, and E. porteriana (s.s.) and E. garberi G3 (= Vulnerable) species.

\section{KEY TO EUPHORBIA HAMMERI AND RELATIVES IN SOUTHERN FLORIDA}

1. Capsules uniformly pubescent; foliage generally pubescent

Euphorbia garberi

1. Capsules glabrous, or slightly pubescent on the angles only; foliage glabrous to rarely slightly pubescent.

2. Leaves (2.2-)3.0-6.0(-8.3) × longer than wide, narrowly lanceolate to linear elliptic, 1-veined, glands of the cyathia narrower than or equal to the gland appendages in radial dimension; cyathia, glands, gland appendages, capsules, and stems light to deep red to purple; [mainland southern Florida]

Euphorbia hammeri

2. Leaves $0.01-3.0(-3.5) \times$ longer than wide, ovate to lanceolate, 1-3-veined, glands of the cyathia wider than the gland appendages in radial dimension; cyathia, glands, gland appendages, capsules, and stems light green to light red; [mainland southern Florida, or Florida Keys].

3. Leaves linear-elliptic, (1.0-)1.8-2.5(-3.5)× longer than wide, 1-veined to weakly 3-veined; leaf apex acute; glands of the cyathia $0.4-0.6 \mathrm{~mm}$ in lateral dimension; [Florida Keys]

Euphorbia ogdenii

3. Leaves ovate-elliptic, 1.0-1.7(-2)× longer than wide, 3-veined; leaf apex obtuse to rounded; glands of the cyathia 0.6-1.0 $\mathrm{mm}$ in lateral dimension; [mainland southern Florida]

Euphorbia porteriana 


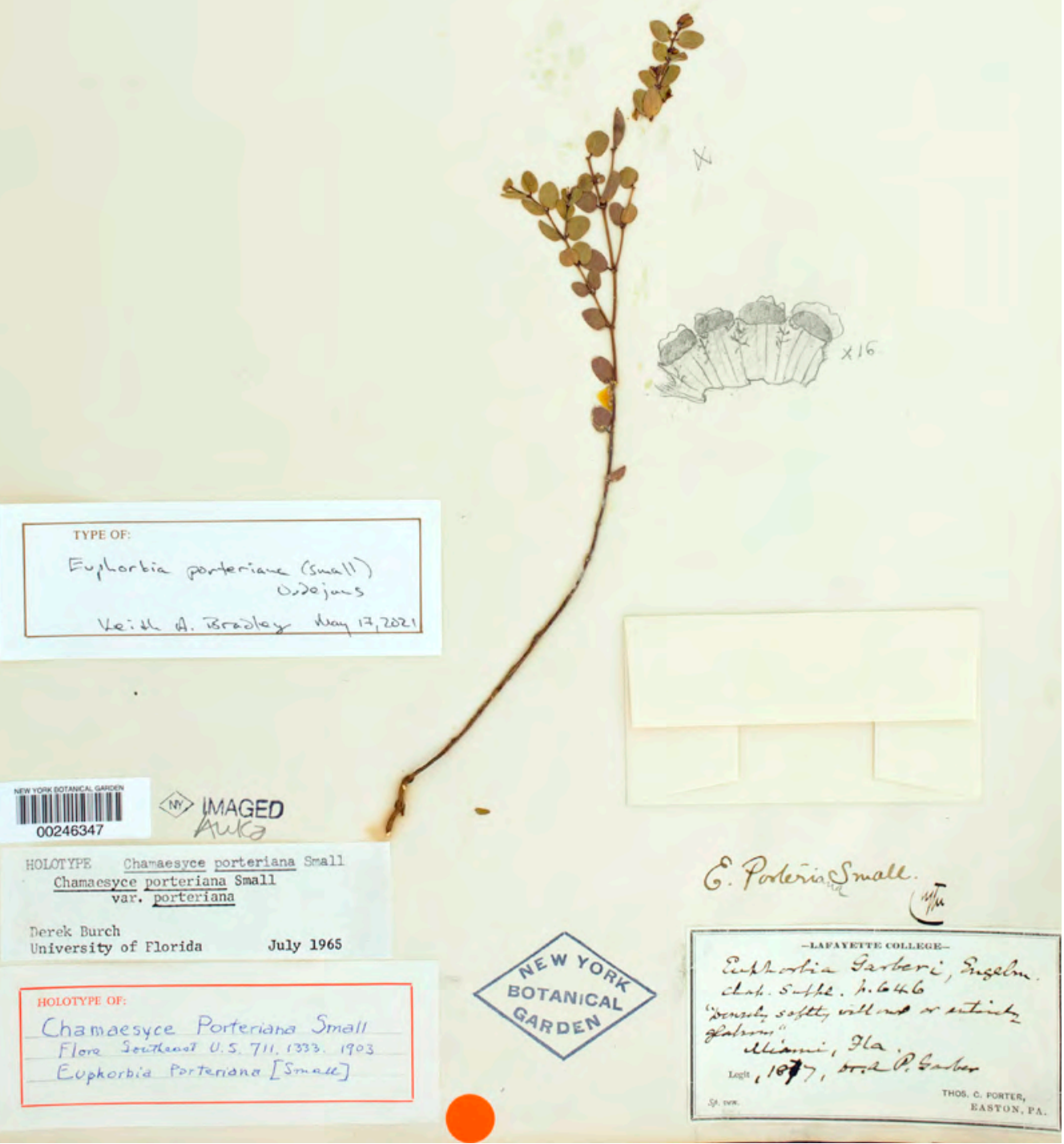

FIG. 9. Euphorbia porteriana. Holotype, Garber s.n., NY. 


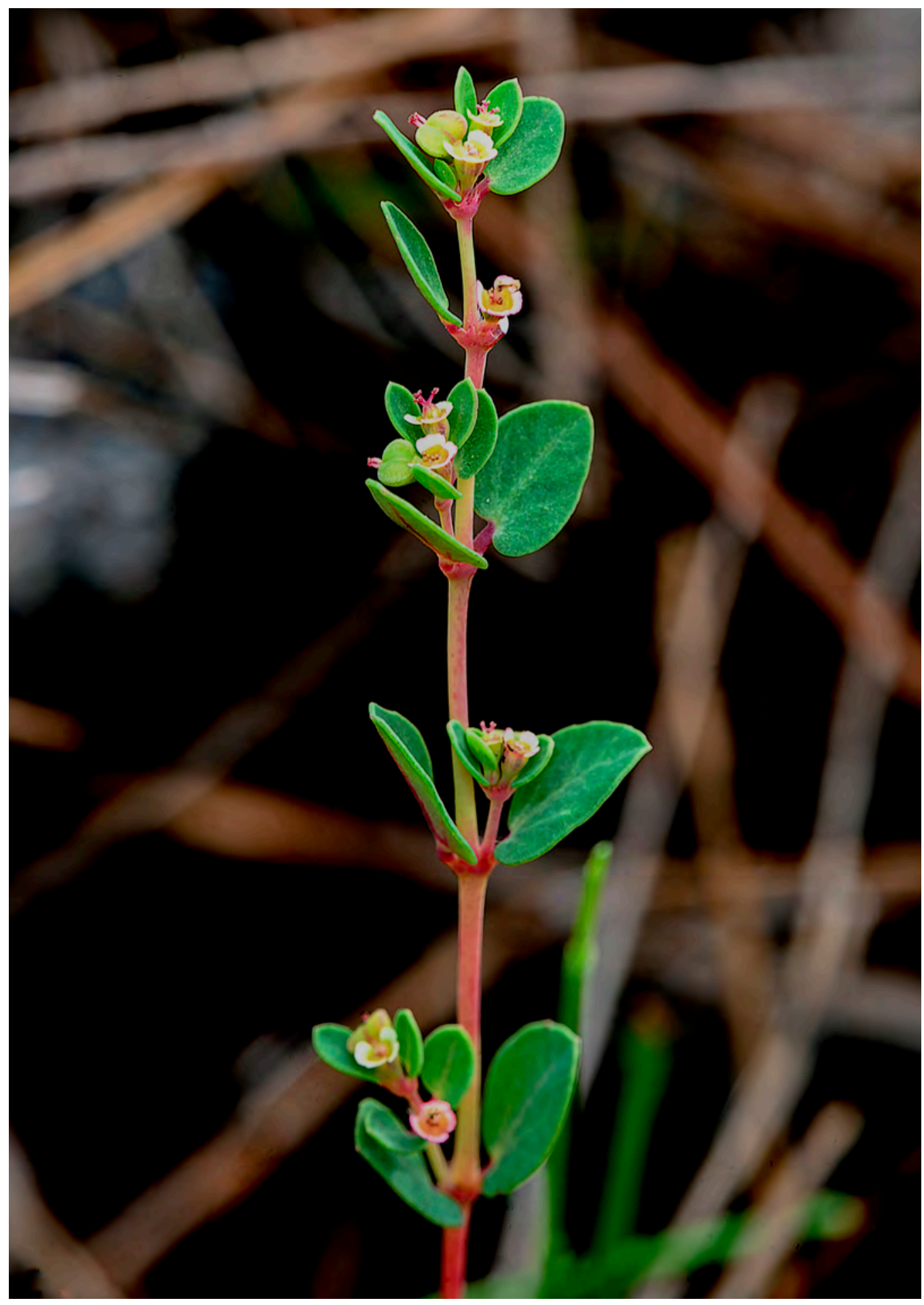

Fig. 10. Euphorbia porteriana. Miami-Dade County, Everglades National Park (photo by Roger L. Hammer). 


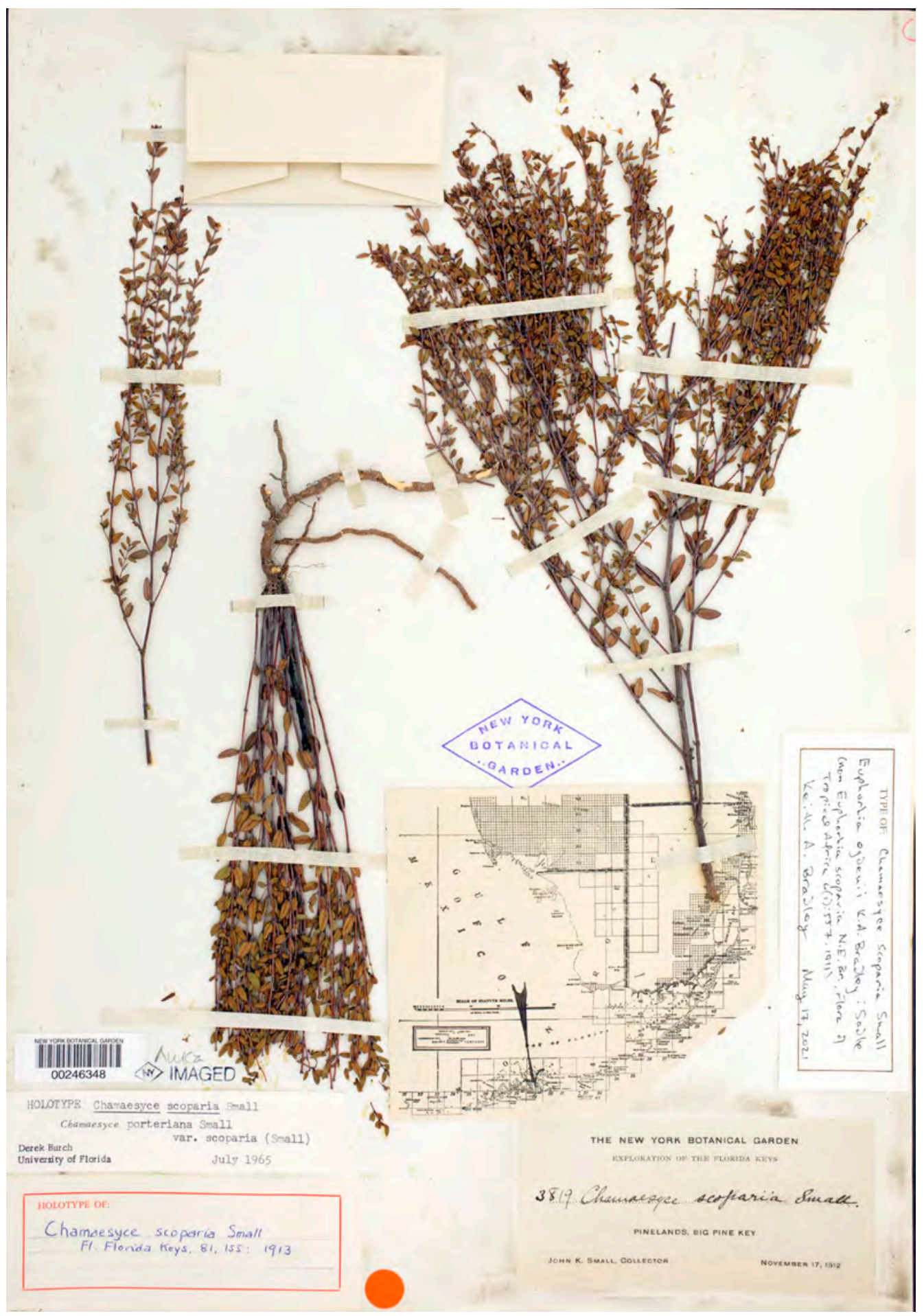

FIG. 11. Euphorbia ogdenii. Holotype, Small 3819, NY. 


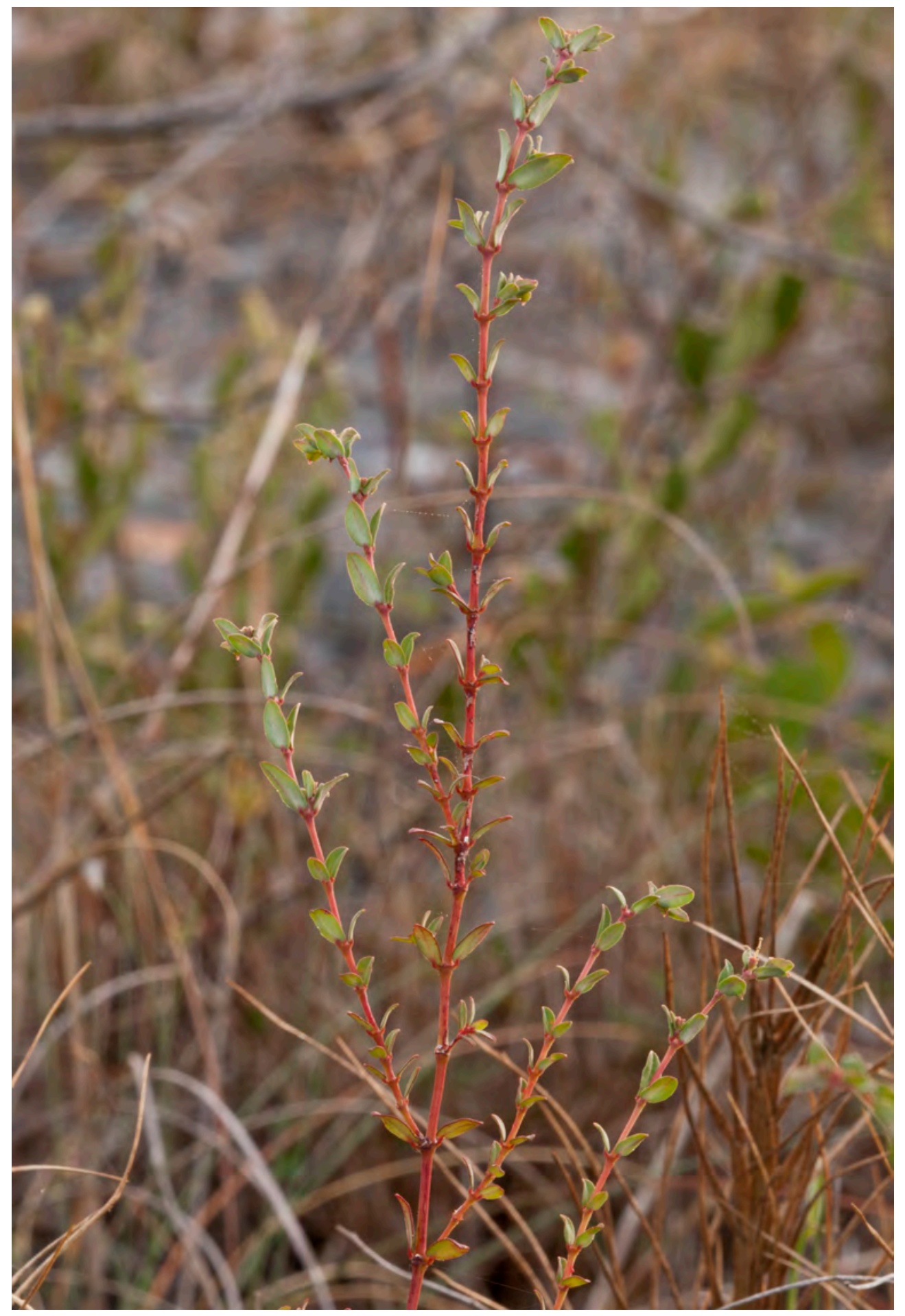

FIG. 12. Euphorbia ogdenii. Monroe County (photo by Keith A. Bradley). 


\section{FABACEAE}

Chamaecrista: Chamaecrista horizontalis, a new species of the Southeastern Plains ecoregion, is distinct from C. deeringiana, a species endemic to the southern Florida pine rocklands.

Primary author: Alan R. Franck

Chamaecrista fasciculata (Michx.) Greene is a tap-rooted, usually monocarpic species that is widespread in the eastern United States. It is typically treated as a polymorphic species (Irwin \& Barneby 1982) or comprising a few varieties (Isely 1975, 1998; Weakley 2020), but historically had been separated into eight species in North America (Britton \& Rose 1930; Small 1933). Perennial plants with the main root(s) horizontal (Pullen 1963; Fig. 13), which otherwise appear superficially identical to $C$. fasciculata, have been referred to as $C$. deeringiana Small \& Pennell. Chamaecrista deeringiana was first considered endemic to extreme southern Florida (Pennell 1917; Britton \& Rose 1930; Small 1933) in the Southern Florida Coastal Plain ecoregion, and the name was later applied to plants in the southwestern part of the Southeastern Plains ecoregion (EPA 2003) of Alabama, Florida, Georgia, and Mississippi (Cronquist 1949; Pullen 1963; Irwin \& Barneby 1982; Sorrie \& Leonard 1999).

Closer scrutiny reveals that $C$. deeringiana should be reverted to its original concept as endemic to extreme southern Florida, and that perennial plants in the Southeastern Plains ecoregion are morphologically distinct, here described as a new species, $C$. horizontalis. Root length, anther color, and habitat distinguish the two perennial species, which are separated by ca. $700 \mathrm{~km}$. Chamaecrista deeringiana has been frequently misapplied to plants in peninsular Florida north of Miami and the Keys, but none are known to be perennial with the primary root horizontal. In the literature, the subterranean, horizontal parts of these perennial species have been described as roots or rhizomes, but from anatomical studies of transverse sections, Pullen (1963) concluded they were roots, not rhizomes.

Notably, the recognition of two species formerly lumped into $C$. deeringiana makes each an endemic species fitting sensibly into the typical endemism patterns in the southeastern United States Coastal Plain (Sorrie and Weakley 2001). Chamaecrista horizontalis is an East Gulf Coastal Plain endemic (Pattern \#10), a pattern shared by more than 80 vascular plant taxa, and $C$. deeringiana (in its narrowed circumscription) is an exemplar of Subtropical Florida endemism (Pattern \#9), which has over 50 endemic vascular plant taxa (Sorrie \& Weakley 2001). Each species is now recognized as a narrow endemic (C. deeringiana) or moderately narrow endemic (C. horizontalis), and each warrants a conservation rank of G3 (= Vulnerable) (NatureServe 2020).

Based on field work and herbarium studies, Pullen (1963) concluded that the perennial species (here as $C$. deeringiana and $C$. horizontalis) do not hybridize with $C$. fasciculata. The perennial species are relatively short plants (to $60 \mathrm{~cm}$ tall) and usually have several stems arising from the horizontal root (Fig. 13). Pullen (1963: 32) found that the growth form of the perennial species was maintained between field and greenhouse plants, while branching habits and height among the eight varieties of $C$. fasciculata recognized by him noticeably varied. Crossing experiments with greenhouse plants of various taxa were inconclusive and no F1 progeny were raised from the very few fruits that did develop (Pullen 1963).

Chamaecrista deeringiana Small \& Pennell in Pennell, Bull. Torrey Bot. Club 44:345. 1917. (Figs. 13A, 13C,

14). Type: U.S.A. Florida. Miami-Dade Co.: near Silver Palm, 22 Jun 1915, Small et al. 6454 (ноцотуPE: NY00004028).

Chamaecrista deeringiana is endemic to the pine rocklands of southern Florida (Miami-Dade Co.). The species is distinguished by its perennial, horizontal roots usually bearing several main stems and the predominantly dark red to purple-red anthers. The horizontal roots so far measured from herbarium specimens do not exceed $20 \mathrm{~cm}$ long (Franck 5278, FTG). Occasionally, the dark red to purple-red anthers of C. deeringiana can be yellow towards the base, as illustrated by Eaton (in Small 1919); in the protologue, Small and Pennell described the anthers as "yellow or reddish."

Anther color is useful for identifying C. deeringiana in southern Florida, at least in live plants or recently collected herbarium specimens. Within the range of $C$. deeringiana, the anthers of $C$. fasciculata are only yellow to yellow-brown. As herbarium specimens age, the anthers darken in both taxa, making anther color difficult 

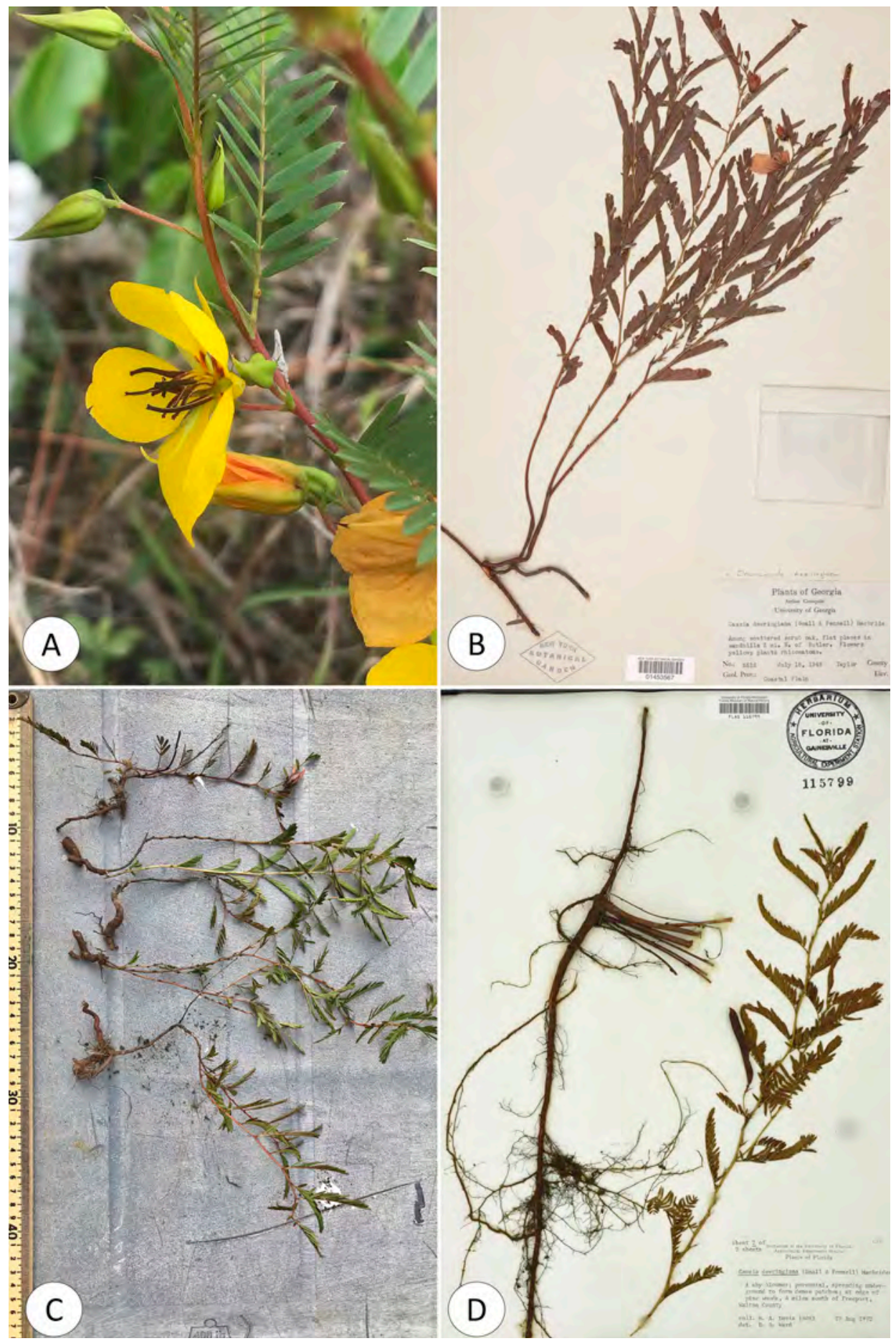

FIG. 13. A, C. Chamaecrista deeringiana, Goulds, Miami-Dade Co. (photos by A.R. Franck). B. Chamaecrista horizontalis, isotype (NY); image courtesy of the C.V. Starr Virtual Herbarium of the New York Botanical Garden, http://sweetgum.nybg.org/science/vh/. D. Chamaecrista horizontalis, Davis 16081 (FLAS, sheet 2 of 2); image by Sophie Charles, courtesy of the University of Florida Herbarium (FLAS), Florida Museum of Natural History. 


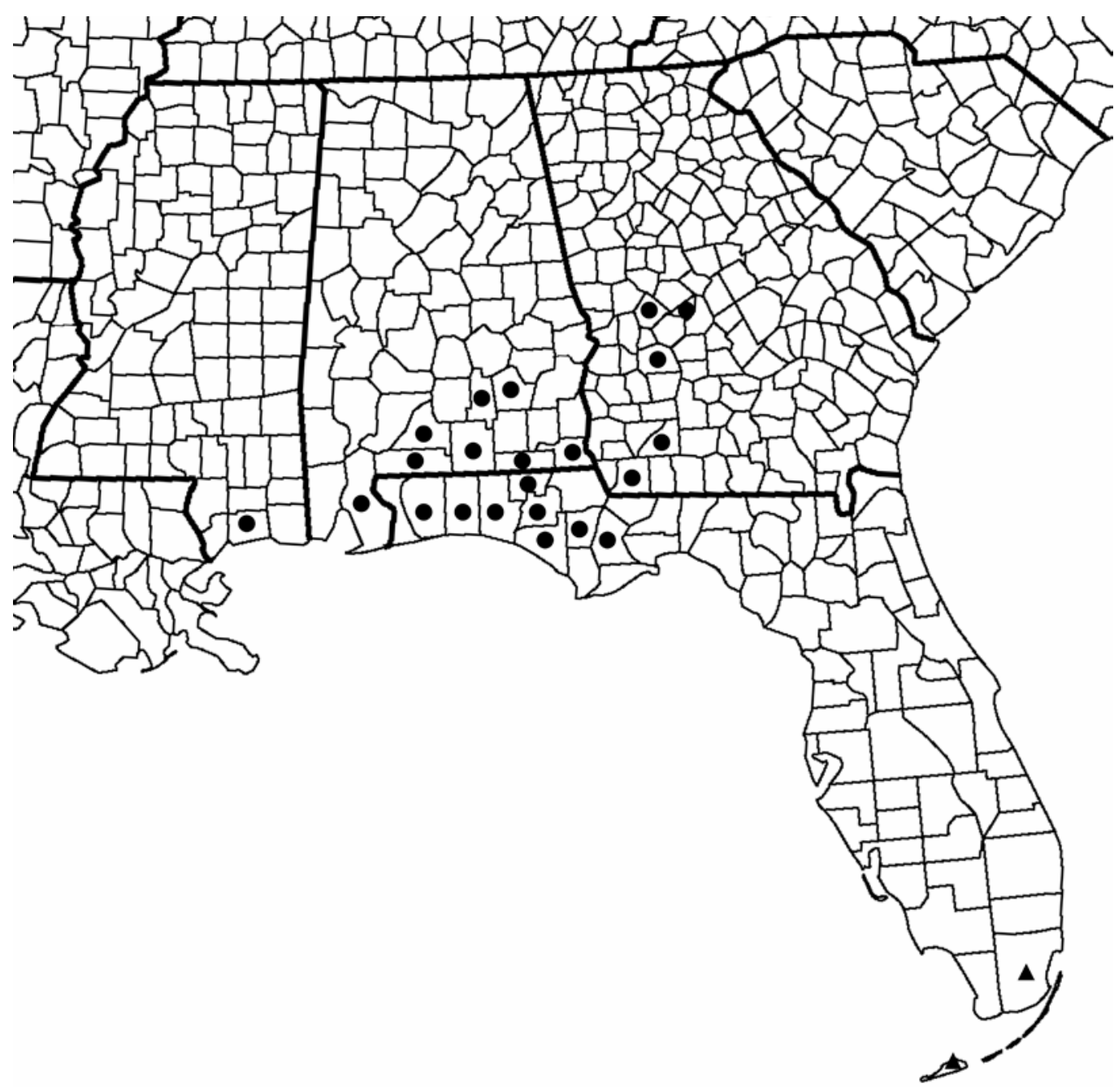

FIG. 14. Distribution of Chamaecrista deeringiana (triangles) and C. horizontalis (dots). Occurrences of C. horizontalis in Bay Co. and Holmes Co., Florida, and Sumter Co., Georgia, are based on specimens that were cited in Pullen (1963), and the occurrence in Mississippi is based on Sorrie and Leonard (1999).

to discern. In addition, the leaflets of $C$. deeringiana seem to age to a dark red-brown color on herbarium specimens and have more pronounced, prominulous lateral veins on the lower surface, compared to the usually more greenish leaflets of $C$. fasciculata in Miami-Dade County with less pronounced, less prominulous lateral veins.

While the dark red to purple-red anthers of $C$. deeringiana are diagnostic locally, anther color ranges from yellow to purple-red in C. fasciculata. Pullen (1963) recognized eight entities at the rank of variety within $C$. fasciculata but several do not have valid varietal combinations in Chamaecrista (L.) Moench. Five of the entities had an anther color described as "mostly yellow grading through mixtures to occasionally red." Only in two of Pullen's entities (corresponding to C. ferrisiae Britton and C. rostrata Wooton \& Standl.) were the anthers described as merely "red" and in C. tracyi Pollard they were described as mostly yellow in the eastern part of its distribution and mostly red in the western part (Pullen 1963). 
The anther colors of $C$. deeringiana are virtually identical to those of $C$. keyensis Pennell, which is similarly perennial and endemic to the pine rocklands of southern Florida. Curiously, the two species may be allopatric. The pine rocklands of the lower Florida Keys (e.g., Big Pine Key, Monroe Co.) host C. keyensis, while C. deeringana is found in the pine rocklands of mainland Miami-Dade County. There is one historic collection (Long $\mathcal{E}$ Andorfer 2824, USF) of C. keyensis allegedly from mainland Miami-Dade County (Brickell Hammock). It is not certain if $C$. deeringiana occurs in the Florida Keys of Monroe County. There is one collection (Lester 104, FTG) from Big Pine Key made in 1966 here tentatively identified as C. deeringiana; the specimen is a solitary, unbranched stem that appears to have been removed from the base of the plant.

There is one historic collection (Small 3781, NY) of C. fasciculata made in 1912 from the pinelands of Big Pine Key that has been misidentified as C. deeringiana by Small, Pennell, and Irwin and Barneby (Pennell 1917). Their identification appears to be solely reliant on the location and habitat. Only the distal portions of the stems are present on the specimen, which have been cleanly cut from the rest of the plant, probably because the plant was rather tall for a herbarium specimen, which would be typical of C. fasciculata. Chamaecrista deeringiana is a rather short plant usually with multiple basal stems that fits easily onto a typical herbarium sheet, and Small likely would have collected the entire aboveground portion (and sometimes the horizontal root), as done with his other specimens of $C$. deeringiana. This very old specimen (Small 3781) also has olive green leaflets, which is typical of old specimens of $C$. fasciculata. The leaflets of old specimens of $C$. deeringiana are rather consistently dark reddish. The Small 3781 specimen from Big Pine Key is still remarkable as the only known specimen of $C$. fasciculata from the Florida Keys of Monroe County. There is a similar specimen (Small $E$ Carter 832, NY) of C. fasciculata from Miami-Dade County that was misidentified as C. deeringiana. Finally, there is a specimen presumably collected by John Loomis Blodgett of only one cutting identified by Pullen as $C$. fasciculata var. fasciculata, which only bears the note "Key West + Charlotte H." (GH01852044); it is probably from Charlotte Harbor (Charlotte Co.), but that cannot be confirmed.

Possibly, one of the oldest collections of $C$. deeringiana is a specimen from the A.W. Chapman herbarium. It consists of two solitary, unbranched stems ca. $25-28 \mathrm{~cm}$ long, one of which is knobby at the base, as if removed from the base of the plant. The specimen appears consistent with $C$. deeringiana. Chapman did not collect in Miami-Dade County but he did travel along the southwest coast (e.g., Caxambas, Palm Cape; Chapman 1878) and is said to have visited Blodgett in Key West in 1843 (Ledin 1953; Ward 2009). Chapman (1878) was familiar with many plants collected by Garber from Miami, and perhaps Garber is the source of this apparent specimen of $C$. deeringiana.

The name $C$. deeringiana has been misapplied frequently to plants of $C$. fasciculata in the Florida peninsula outside of Miami-Dade County (e.g., Pullen 1963; Irwin \& Barneby 1982; Isely 1998), but none exhibit the characteristic horizontal perennial roots of $C$. deeringiana. Examples include specimens without roots (e.g., Martin Co., Beck s.n., FLAS) or those with taproots typical of C. fasciculata (e.g., Hendry Co., Beardsley s.n., FLAS); some are somewhat anomalous with numerous stems clustered at the base (Hernando Co., Kral 6821, GH, USF and Okeechobee County, McCart 10756, FLAS). McCart 10756 was collected from a roadside, so it is possible the plant had been previously mown. Pullen (1963) conducted extensive fieldwork in numerous counties throughout Florida, collecting several taxa of Chamaecrista, and yet he collected C. deeringiana only in Miami-Dade County and he collected C. horizontalis only in the counties cited for it below.

The chromosome number of $C$. deeringiana was determined to be $n=8$ (Pullen 1963). This same chromosome number was determined for seven of the eight entities of C. fasciculata treated by Pullen (1963).

Specimens examined: U.S.A. FLORIDA. Miami-Dade Co.: near Long Prairie, 24 Mar 1904, Britton 197 (NY); between Homestead and Camp Jackson, May 1904, Small 1876 (NY); near Murden Hammock, 22 Jun 1915, Small \& Mosier 6435 (FTG, NY); eastern end of Long Key, Everglades [mistakenly attributed to Monroe Co. by Pullen 1963], Apr 1917, Small 8124 (US); W of Coconut Grove, 15 May 1918 , Small 8787 (DUKE, GH, NCU, TENN, US); Royal Palm State Park [mistakenly attributed to Collier Co. by Pullen 1963], 2 Feb 1928, Hawkins s.n. (FLAS); Cutler, 21 Jul 1948, Woodbury s.n. (FTG); near Long Pine Key, 22 Apr 1958, Traverse 575 (GH); Richmond Naval Air Station, 5 May 1968, Owen s.n. (FTG); Montgomery Foundation, 20 May 1969, Gillis 8068 (FTG, GH, USF); Deering Estate, 27 May 1978, Correll E Popenoe 49828 (FTG); Pine Shore Park, 2 Aug 1997, Bradley 617 (FTG); Seminole Wayside Park, 20 Mar 1998, Woodmansee E Hoffman 38 (FTG); Goulds Pineland, 7 Jun 1998, Bradley 1804 (FTG); Rockdale Pineland, 16 Jul 1998, Bradley 1932 (FTG); Navy Wells Pineland, 12 Aug 1992, 
Orzell \& Bridges 20412 (USF); Princeton, 12 Jul 2015, Franck 3928 (USF); ibid., 17 Jan 2021, Franck 5108 (FTG); ibid., 3 May 2021 , Franck 5278 (FTG). Monroe Co.: Big Pine Key, 23 Apr 1966, Lester 104 (FTG). Unknown Co.: "Herb. Chapman" (NY01453563).

Chamaecrista horizontalis A.R. Franck, sp. nov. (Figs. 13B, 13D, 14). Type: U.S.A. Georgia. Taylor Co.: 3 mi N of Butler, 18 Jul 1948, Cronquist 5516 (hoLotyPE: GA039438; I5OTYPES: FLAS51702, GH01873982, IND0049273, LSU0067554, NY01453567, US00366391).

Diagnosis.-Chamaecrista horizontalis is placed in Chamaecrista ser. Chamaecrista owing to its pinnately veined leaflets, supra-axillary inflorescence arising along the stem between two leaf nodes whereby the peduncle is adnate to the stem internode, and sepals with inconspicuous venation. Within this series, $C$. horizontalis is distinguished by its perennial and horizontal main root to $46+\mathrm{cm}$ long, usually several erect main stems mostly narrower than the horizontal root, leaves usually with 8 or more leaflets, relatively large flowers over $1 \mathrm{~cm}$ wide, and yellow to yellow-brown anthers.

Description.-Plant perennial, herbaceous, $30-60 \mathrm{~cm}$ tall. Primary root generally horizontal, 2-7 mm wide, to $46+\mathrm{cm}$ long, with scattered finer roots. Stems erect to erect-ascending, unbranched or basally few-branched, straight to slightly zigzagged, sometimes curved near the base, terete to slightly ridged, the ridges decurrent from the petiole and stipules, glabrous to puberulent, $1-2.3 \mathrm{~mm}$ wide, often clustered along the primary root or in fascicles of up to 12 stems, the fascicle sometimes on a short stipe, stipe to $5 \mathrm{~mm}$ wide, to $16 \mathrm{~mm}$ long. Stipules lanceolate-subulate, (2-)3.6-8 $\mathrm{mm}$ long, 0.6-2 $\mathrm{mm}$ wide, smaller towards the base of the plant. Leaves alternate, paripinnate, (2-)16-34-foliolate, the leaflets opposite, leaves in proximal third of the stem typically with fewer leaflets, the basal-most leaf as few as 2-foliolate, rachis (0-)1.6-3.9 cm long, ca. $0.5 \mathrm{~mm}$ wide, petiole glabrous to puberulent, $2-5 \mathrm{~mm}$ long, ca. $0.5 \mathrm{~mm}$ wide, subtended by the $1-2 \mathrm{~mm}$ long pulvinus, petiolar gland near or at mid-petiole, sessile, discoid to ellipsoid, to $1 \mathrm{~mm}$ wide, to $1 \mathrm{~mm}$ long. Leaflets oblongelliptic, glabrous, (5.5-)8-18 mm long, 1.8-5 mm wide, asymmetric, the portion of the blade on the proximal side of the midrib up to twice as wide as the distal side, usually awned at the apex, the awn to $1 \mathrm{~mm}$ long, the midrib abaxially pronounced and prominulous, with 4-11 lateral veins, the veins adaxially obscure, abaxially obscure to pronounced and prominulous, pulvinuli ca. $0.5 \mathrm{~mm}$ long, $0.5-0.8 \mathrm{~mm}$ wide. Inflorescence solitary or in fascicles of 2, arising from the stem 2-6 mm above the subtending leaf (the peduncle adnate to the stem), with a solitary flower. Pedicel glabrous to puberulent, $12-19 \mathrm{~mm}$ long, ca. $0.5 \mathrm{~mm}$ wide, slightly thicker in fruit, subtended by two bracts attached to the stem, $5 \mathrm{~mm}$ long, $1.3 \mathrm{~mm}$ wide, with two bracteoles above the middle, 2.9-4 mm long, 0.9-1.1 mm wide. Sepals 5, lanceolate-subulate, glabrous or medially sparingly puberulent abaxially, 11.7-14 mm long, 1.6-2.4 mm wide. Petals 5, yellow, sometimes with a red spot at the base, obovate, the two apical petals $11-15 \mathrm{~mm}$ long, 5-7.5 mm wide, the two lateral petals $15-19 \mathrm{~mm}$ long, 6-9 mm wide, the basal petal 15-19 mm long, 10-15 mm wide. Anthers 10, yellow to yellow-brown, straight to arcuate, 6.5-11 mm long, the filament ca. $1 \mathrm{~mm}$ long. Style yellow, incurved, 8-12 mm long. Fruit linearrhomboid, glabrous to puberulent, dehiscent, with 7-12 partitions, $4.2-5.3 \mathrm{~cm}$ long, $0.4-0.6 \mathrm{~cm}$ wide. Seed not observed.

Chamaecrista horizontalis is known from the pinelands and oak woodlands of southern Alabama, southwestern Georgia, southeastern Mississippi, and the western Florida panhandle. Plants have yellow to yellowbrown anthers, as apparent from specimen labels, recent herbarium specimens, and live plants (Keener et al. 2021). The horizontal roots of $C$. horizontalis probably can exceed $46 \mathrm{~cm}$ long, as the longest on herbarium specimens (e.g., Davis 16081, FLAS and Adams \& Tyson 838, FSU) appear to be cut or broken. Further, Pullen (1963: 23) was presumably referring to this species when he stated that clones of up to four meters in diameter have been observed.

In 1948, Cronquist collected plants of C. horizontalis in Taylor County, Georgia, and applied the name C. deeringiana since he thought his plants were "clearly identical with the [southern] Florida plant" (Cronquist 1949). In March 1962, Erdman West added an annotation on Godfrey 61238 (FLAS) that reads, "A perennial rhizomatous form from West Florida for which we have not yet found a name." In agreement with Cronquist (1949), Pullen (1963) applied the name C. deeringiana in the wide sense to include those plants here called $C$. horizontalis.

Later authors continued applying the name $C$. deeringiana to perennial plants in Alabama, Georgia, Mississippi, and the Florida panhandle (Pullen 1963; Irwin \& Barneby 1982; Isely 1975, 1998; Chafin 2007; 
Weakley 2020; Keener et al. 2021). Isely (1975, 1998) did not include Alabama, Georgia, or Mississippi in the range of $C$. horizontalis (using the misapplied name $C$. deeringiana), although he annotated some Georgia specimens as C. deeringiana (e.g., Buckner s.n., GA and Duncan \& Hardin 13615, GA).

The yellow to yellow-brown anthers of $C$. horizontalis distinguish it from $C$. deeringiana with its dark red to purple-red anthers (sometimes yellow towards the base). Herbarium specimens suggest that the horizontal roots of $C$. horizontalis are longer than those of $C$. deeringiana, which could be a consequence of their differing habitats. A common garden experiment would probably be necessary to determine if their root lengths actually differ. Flowering time appears to be restricted to late May to early August in C. horizontalis, while C. deeringiana can flower year-round in Miami-Dade County, Florida, where freezing temperatures usually do not occur

Specimens examined: U.S.A. ALABAMA. Baldwin Co.: 6.9 mi NE of Bay Minette, 2 Jun 1970, Kral 39533 (GH); W of route 112 , 1.1 mi N of jct. with C-64, 22 Jun 1997, Sorrie 9327 (NCU). Conecuh Co.: US 31, E side of Sepulga River, 4 Jul 2013, Diamond 24306 (TROY, UWAL). Covington Co.: 15 Jun 1999, MacDonald 13023 (MISSA, TROY); 4.5 mi E of Florala, 8 Jul 1999, Stewart \& MacDonald 6741 (DSC); Crooked Road, 20 May 2011, Diamond 22135 (TROY, UWAL). Crenshaw Co.: 4 Sep 1997, Diamond 11115 (AUA). Escambia Co.: 8.8 air mi NW of Flomaton, 21 Jun 2007, Schotz 2061 (UNA). Geneva Co.: Geneva State Forest, 15 Jun 1999, MacDonald E Warren (DUKE). Houston Co.: 29 May 1999, MacDonald 12901 (TROY). Pike Co.: 17 Jun 2016, Diamond 27488 (TROY). FLORIDA. Calhoun Co.: 0.75 mi S of Clarksville, 20 Jul 1954, Ford 3398 (FLAS); 4.5 mi NW of Clarksville, 31 Jul 1957, Ford 5006 (FLAS). Liberty Co.: near Bristol, 22 Jul 1940, West \& Arnold s.n. (FLAS). Okaloosa Co.: 2 mi W of Laurel Hill, 2 Aug 1961, Godfrey 61297 (FSU); 3.5 mi SW of Laurel Hill, 2 Aug 1961, Godfrey 61309 (FSU); ibid., Godfrey 61331 (FSU, USF). Santa Rosa Co.: 15 mi SE of Milton, 30 May 1967, Smith 1360 (FLAS); 11 mi N of Holley, 21 Jun 1967, Smith 1538 (FLAS). Walton Co.: 10 mi S of DeFuniak Springs, 3 Jun 1954, West \& Arnold s.n. (FLAS); Eglin Air Force Reservation, 13 Sep 1955, West s.n. (FLAS); vicinity of Buffalo Lake, N of DeFuniak Springs, 2 Aug 1961, Godfrey 61238 (FLAS, FSU, GH, US, USF); 4 mi S of Freeport, 7 Aug 1972, Davis 16074 (CM, FLAS [2 sheets]); ibid., 25 Aug 1972, Davis 16081 (FLAS); ibid., 14 Aug 1977, Ward 9205 (FLAS [2 sheets]); ibid., 31 Aug 1982, Davis \& Davis s.n. (FSU). Washington Co.: post office of Crystal Lake, 29 Jul 1954, Ford 3739 (FLAS); 24 Jun 1961, Adams \& Tyson 838 (FSU [2 sheets], UWFP). GEORGIA. Decatur Co.: 12 mi W of Bainbridge, 10 Jun 1966, Buckner s.n. (GA, LSU), Mitchell Co.: 3.2 air mi NW of Bridgeboro, 17 Jul 2007, Carter \& Baker 17729 (MMNS, VSC). Peach Co.: Fort Valley, Jul 1915, [unknown collector] E3340 (GA). Taylor Co.: 6 mi W of Butler, 15 Jun 1952, Duncan \& Hardin 13615 (GA).

\section{KEY TO CHAMAECRISTA DEERINGIANA, C. FASCICULATA, AND C. HORIZONTALIS}

1. Plant usually monocarpic, $20-140(-240) \mathrm{cm}$ tall, with a branched vertical taproot gradually reduced to finer roots, the taproot grading into the main stem; main stem usually solitary (rarely multiple) from the base of the plant, glabrous, sparsely to densely puberulent, pubescent, pilose, to hirsute, 2-13 $\mathrm{mm}$ wide at the base

C. fasciculata

1. Plant perennial, $30-60 \mathrm{~cm}$ tall, the main root horizontal and generally perpendicular to the main stems; main stems usually several (rarely solitary) from the base of the plant, glabrous to sparsely puberulent, 1-7 mm wide at the base.

2. Horizontal root to ca. $20+\mathrm{cm}$ long; anthers dark red to purple-red, sometimes yellow towards the base; flowering year-round, but especially Mar-Aug; [pine rocklands of southern Florida]

C. deeringiana

2. Horizontal root to ca. $46+\mathrm{cm}$ long; anthers yellow to yellow-brown; flowering late May-early Aug; [sandy and clayey pine and oak woodlands of southern Alabama, southwestern Georgia, southeastern Mississippi, and the western Florida panhandle]

C. horizontalis

\section{MALVACEAE}

Waltheria: Waltheria bahamensis in Florida

Primary author: Alan R. Franck

Waltheria indica L. is a pantropical weed with a lectotype with provenance from Sri Lanka. Across its distribution, the species is closely related to and possibly interfertile with several local taxa, making delineation of taxa difficult (Saunders 1995, 2011, 2015). This pattern holds true in Florida, where W. bahamensis Britton is quite distinct from $W$. indica except that a few specimens suggest they may hybridize. For a long while, $W$. indica was considered the only species in Florida (Chapman 1860; Rose 1899; Whetstone 1983; Wunderlin \& Hansen 2011) and W. bahamensis was treated as an endemic of the Bahamas (Britton \& Millspaugh 1920; Freid et al. 2014), until a revision of the genus determined W. bahamensis was applicable to the Florida flora (Saunders 1995, 2015).

The type of W. bahamensis has numerous spreading stems arising from the very base of the plant, with most of the stems quite narrow. The overall form of the type suggests that the plant was prostrate to decumbent, but the type collection and earlier accounts did not describe the orientation of the stems (Northrop 1902; 
Britton 1903; Britton \& Millspaugh 1920; Gillis 1974; Correll \& Correll 1982). More recently, W. bahamensis was defined as a shrub to 0.6 (rarely 1 ) $\mathrm{m}$ tall, with stems prostrate, decumbent, to spreading, and leaf blades mostly sparsely stellate-pubescent with the arms of stellate hairs to $0.5 \mathrm{~mm}$ long (Saunders 1995, 2015).

The type specimens and descriptions of W. bahamensis match numerous specimens in Florida (Fig. 15A, 15B). In Florida, Waltheria bahamensis is associated with relatively undegraded habitats and it has an oddly disjunct distribution, in the coastal strands of the Gulf Coast, the Lake Wales ridge scrub, and rocklands of Miami-Dade and the Florida Keys. Its occurrence in high-quality habitat supports the contention that it is a native component of the Florida flora.

Waltheria indica is weedy and fond of disturbed sites, including disturbed edges of habitats typical for W. bahamensis. Two specimens, one from the Bahamas and one from Sanibel Island, Lee County, Florida, were cited as intermediate between W. bahamensis and W. indica (Saunders 1995); likewise, the pubescence of Gillis 11458 (FTG) of Key Biscayne, Miami-Dade County, Florida seems to approach W. indica, yet its numerous stems from the base align well with W. bahamensis.

The growth habit and leaf blade pubescence are useful for distinguishing the two species of Waltheria in Florida. The flowers of W. bahamensis are reportedly slightly smaller than those of W. indica, and the capsule of W. bahamensis possesses a puberulent line at the apical valve margin that is lacking in W. indica (Saunders 1995, 2015). The hirsutulous pubescence of the style of the two taxa (e.g., illustrated on the lectotype of $W$. bahamensis) seem very similar (Saunders 1995), although Saunders (2015) described it as sericeous in W. bahamensis.

There is reportedly some variability in the leaf blade color of W. bahamensis, as currently defined, from green to bronze or dark reddish. Originally, the leaf blades of W. bahamensis were described as dark green and paler below (Britton 1903; Britton \& Millspaugh 1920). Prostrate to decumbent plants that appear very similar to the type collection have been observed with green to olive leaf blades (e.g., Fig. 15A, Lee County, Florida and https://www.inaturalist.org/observations/63757629, Grand Bahama, Bahamas). Recent literature has described the leaf blades as tinged reddish or brown, usually bronze-tinged, dark brown, or coppery, and further considered such a color to be diagnostic of the species (Gillis 1974; Correll \& Correll 1982; Saunders 1995, 2015; Freid et al. 2014: Fig. 2f). Bronze, coppery, or dark reddish leaf blades are not known on any Florida specimens, except one occurrence from Miami-Dade County (Fig 15C). Notably, this occurrence (Fig. 15C) was found adjacent to green-leaved plants of $W$. indica and it was recorded during a very wet time of year; thus, it is difficult to reconcile this observation as a simple consequence of temporal stress (Chalker-Scott 1999). Further investigation of leaf blade color and the taxonomy of Waltheria L. in Florida and the Bahamas is warranted.

Saunders (2015) reported hybrids between Waltheria glabra Poir. (a species from Guadeloupe) and W. bahamensis in Florida, and a specimen (Correll \& Correll 52704, FTG) was annotated as W. cf. rotundifolia Schrank (a species from Brazil). Given the absence of specimens clearly identified as these species in Florida, it is unclear if either taxon does indeed occur at all in Florida. Two species, W. arenicola A. Rodr. and W. microphylla Cav., both of Cuba, are low-growing plants with small leaves and may need to be critically compared with the similar W. bahamensis.

In the protologue, Britton identified the collection Curtiss 117 as the type but did not specify the herbarium. The NY specimen is here designated the lectotype.

KEY TO SPECIES OF WALTHERIA IN FLORIDA

1. Plant to 0.6(-1) $\mathrm{m}$ tall; stems prostrate, decumbent, to spreading, often several from the base of the plant; leaf blades $1-2 \times$ longer than wide, to $3.4 \mathrm{~cm}$ long and $2.7 \mathrm{~cm}$ wide, the stellate hairs of the upper blade surface not overlapping or scarcely so, the arms of the stellate hairs $0-0.3(-0.5) \mathrm{mm}$ long (rarely a few arms longer); [in Florida: coastal strand, sandy pinelands or scrub, and pine rocklands]

W. bahamensis

1. Plant to $2 \mathrm{~m}$ tall; stems generally erect to ascending, usually solitary at the base of the plant; leaf blades (1.4-)1.8-2.2 $(-3.5) \times$ longer than wide, to $12 \mathrm{~cm}$ long and $6.5 \mathrm{~cm}$ wide, the stellate hairs of the upper blade surface strongly overlapping, the arms of the stellate hairs mostly $0.4-1 \mathrm{~mm}$ long; [in Florida: generally of disturbed sites] 

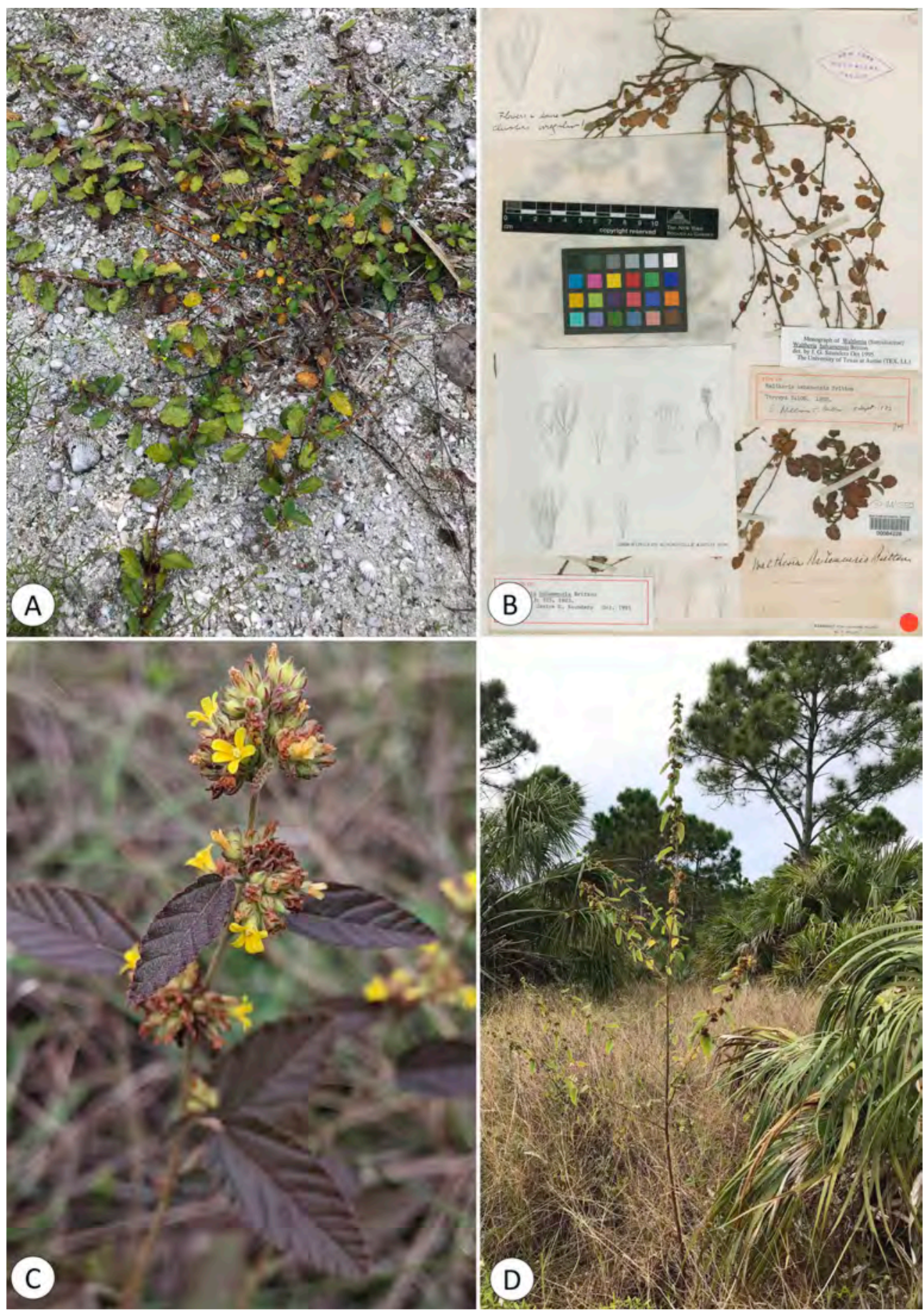

FIG. 15. A. Prostrate plant of Waltheria bahamensis, Sanibel Island, Lee Co., Florida (photo by A.R. Franck). B. Waltheria bahamensis, lectotype (NY); image courtesy of the C.V. Starr Virtual Herbarium of the New York Botanical Garden, http://sweetgum.nybg.org/science/vh/. C. Waltheria cf. bahamensis, Richmond Tract, Miami-Dade Co., Florida (photo by Lydia Cuni; https://www.inaturalist.org/observations/63914024). D. Erect plant of Waltheria indica, ca. $1.7 \mathrm{~m}$ tall, Goulds, Miami-Dade Co., Florida (photo by A.R. Franck). 
Waltheria bahamensis Britton, Torreya 3:105. 1903. Lестотуре, designated here: Bahamas, New Providence, near Nassau, 31 Mar 1903, Curtiss 117 (LectotyPe, NY00084228; ISOLECtotypes, CM183940, E00012600, F144010, F144011, F1538901, GH00056995, GH00056996, HBG512411, K000380991, MO2061649, MPU016438, P02273690, US428621, US428622, VT238821).

Specimens examined: BAHAMAS. Andros: along Red Bays Road, 19 Jul 1969, Proctor 30674 (FTG); Stafford Creek, 1 Feb 1974, Correll \& Godfrey 41507 (FTG); Stafford Creek bridge, 5 Dec 1976, Correll \& Proctor 47749 (FTG). Berry Islands: Anderson Cay, 16 Oct 1974, Correll \& Correll 43664 (FTG). Cat Island: near Wilsons Bay, 25 Oct 1967, Byrne 374 (FTG). Grand Bahama: Queens Way, 18 Mar 1971 , Austin \& Conroy 4574 (FTG). New Providence: near Nassau, 7-8 Apr 1904, Britton 95 (US); Nassau, 8-12 Dec 1949, Woodbury \& Shuttleworth s.n. (FTG [mixed collection with W. indica]). U.S.A. FLORIDA. Highlands Co.: Avon Park, 17 Aug 1934, Davis Jr. (FLAS); below Lake Placid, 3 May 1942, Buswell s.n. (FTG); S of Sebring, 26 Sep 1948, Ledin s.n. (FTG); corner of Lake Leto Road and FLA 17, 5 Sep 1981, Wunderlin \& Beckner 9134 (FTG, USF); off of Route 27 on S edge of Sebring, 2 Oct 1981, Correll \& Correll 52704 (FTG). Lake Co.: E of Clermont, 4 Nov 2000, Abbott \& Carlsward 14133 (MO, SEL). Lee Co.: Captiva, Feb 1915, Orrok s.n. (US); Sanibel Island, 28 Dec 1953, Cooley \& Woodbury, 2464 (FLAS, US, USF); western Sanibel Island, 31 Mar 1965, Brumbach 5065 (FLAS); N Captiva Island, 22 Oct 1978, Morrill \& Harvey 170 (USF); Sanibel Island, Ding Darling Refuge, 28 Oct 1978, Wunderlin et al. 6142 (FTG, USF); 4.5 mi N of Bonita Springs, 12 Sep 1990, Orzell \& Bridges 15201 (FTG, USF); Gasparilla Island, 19 Jun 2006, Saunders 06 (FTG). Miami-Dade Co.: Key Biscayne, 10 Aug 1972 , Gillis 11458 (FTG); S of SW 176th St., off Old Cutler Road, 21 Sep 1973, Correll \& Correll 40097 (FTG); Deering Estate, 28 Jul 1992, Lott DT1438 (FLAS). Monroe Co.: near FL 94, 19 Apr 1964, Godfrey et al. 63524d (FSU); Cape Sable, Northwest Cape, 28 Nov 1916, Small 8039 (US); Cape Sable, Middle Cape, 18 Apr 1964, Godfrey et al. 63497 (FSU, NCU); ibid., 7 May 1965, Lakela \& Long 28583 (USF [sheet 2 of 2 only]); Big Pine Island, 26 Jan 1965, Craighead s.n. (FTG); Geiger Key, 18 Feb 1983, Godfrey 80307 (FSU). Polk Co.: Hesperides, 4 Sep 1960, Lakela 23294 (FSU, USF).

\section{MELANTHIACEAE}

Toxicoscordion: Toxicoscordion nuttallii deleted from the flora of Mississippi and notes on its status in the easternmost states of its range.

Primary author: John Michael Kelley

Toxicoscordion nuttallii (A. Gray ex S. Watson) Rydb. (Melanthiaceae) is a bulbous herb with well-documented presence in the states of Arkansas, Kansas, Louisiana, Missouri, Oklahoma, and Texas. It typically inhabits tallgrass prairies, glades, and woodlands (Schwartz 2003; Weakley 2020) and is considered to be restricted to undisturbed native habitat (Ladd \& Thomas 2015). While considered G5 or Globally Secure (NatureServe 2020) and unranked in four states in its distribution because of being at least relatively secure in each of those jurisdictions, it is ranked S1 (critically imperiled) in Louisiana and Missouri (NatureServe 2020).

After finding a new population in Caddo Parish, Louisiana, I began searching the available literary and herbarium records, requesting accounts from botanists, and revisiting occurrences at the eastern edge of the species' range. I made notes on habitat preferences to aid in further searches for the species in Louisiana and Mississippi.

Kartesz (2015) listed Mississippi within the range of T. nuttallii based on a specimen supposedly housed at LSU and digitized on the herbarium database SERNEC (John Kartesz, pers. comm.). Based on Kartesz (2015), Weakley (2020) attributed the species as occurring in Mississippi. I encountered this specimen online and found that the label data did not appear to match the specimen, and that the county where it was supposedly collected had no suitable habitat, suggesting that the record was dubious. When I requested information from LSU, it was discovered that a T. nuttallii specimen from Caldwell Parish, Louisiana, had been confounded with a Carex L. specimen from Tunica County, Mississippi. I found no other vouchers or accounts for T. nuttallii in Mississippi, thus the species should be presumed to not be a component of the flora of Mississippi. Mississippi has many calcareous prairies and woodlands, but no evidence yet supports the presence of this plant east of the Mississippi River. The extensive digitization of specimens has made distributional information more available, but records should always be additionally vetted to ensure their accuracy.

For Missouri, I found one specimen of Camassia scilloides (Raf.) Cory misidentified as T. nuttallii on SERNEC and one specimen that was collected in Hays County, Texas, filed incorrectly under Texas County, Missouri. I brought these issues to the attention of the appropriate data managers via email. In Missouri, the species is known only from two limestone glades, one on private land and the other on USFS land, neither resurveyed in the last two decades and with known recorded populations of fewer than 100 plants (Mallissa 
Briggler, MONHP botanist, pers. comm.). Considering the very small populations, the S1 rank appears correct.

The Arkansas Natural Heritage Commission currently considers T. nuttallii "too common to track," but the species is under consideration for tracking in the future (Theo Witsell, pers. comm.). The largest populations may occur at Fort Chaffee, but other seemingly viable populations occur in the eastern Ozark dolomite glades and similar habitats across the state. The flora of dolomite glades in northeastern Arkansas has similarities to that of the prairies of northwestern Louisiana, with roughly half of the species present being shared by the two systems (pers. obs.). The species apparently responds favorably to fire in reclaimed grasslands. Hogs may be damaging populations across Arkansas because they appear to be searching for the subterranean parts of this and other bulbous species (Theo Witsell ANHC, pers. comm.). The proximity of some Arkansas populations to Missouri populations makes them ideal donor sites to bolster Missouri's low numbers. While no formal rank has been given, and data are incomplete, a working assessment suggests T. nuttallii is S3S4 (near threatened to apparently secure) in Arkansas.

Louisiana's known populations are within calcareous prairies or the woodlands adjacent to them. The two prairie systems that are known to support T. nuttallii populations are the Morse Clay (Caddo and Bossier parishes; six populations) and the Copenhagen (Caldwell Parish; one population) Jackson series. These systems are under study to clarify and improve the classification of their communities for conservation planning. New Morse Clay prairies have recently been discovered in Webster Parish, Louisiana, and in Columbia County, Arkansas. High-quality remnants similar to the Copenhagen prairies have recently been delineated in LaSalle Parish and are being surveyed floristically (Kelley \& Reid, in prep.); these sites may yield new stations for T. nuttallii in the state.

I revisited known populations of T. nuttallii in the Morse Clay prairies to determine their current population status. I found two Caddo Parish stations presumably extirpated from degradation (last observed 1977 and 1979) and observed no plants at a third, relatively intact station (last observed 1973). The new Caddo Parish population (observed 2020), two in Bossier Parish (last observed 2017 and 2020), and the Caldwell Parish population (last observed 1998, owned and managed by The Nature Conservancy) have been recently observed and are presumed extant, though the largest I observed had fewer than 500 plants. The species is at moderately high risk of being extirpated if its habitat is managed improperly. Because of the small number of populations, their small size, their vulnerability to loss if management is not appropriate, and documented loss of some populations, an S1 (Critically Imperiled) rank for T. nuttallii in Louisiana remains warranted.

Additional surveys with the goal of locating new populations are needed for this species in Louisiana, southern Arkansas, and in non-glade habitats; the following comments and recommendations may assist. I have observed Nemastylis geminiflora Nutt. and Camassia scilloides to be frequent companions to T. nuttallii in Louisiana and Arkansas. The habitats in Louisiana are often moist streamside woodlands with Quercus similis Ashe, Crataegus spp., and diverse herbs. Populations in calcareous woodlands seem to respond favorably to frequent fire, sometimes supplemented by physical canopy reduction. At least two Louisiana stations have been mowed regularly, but stations I considered extirpated may have been lost to this unnatural regime. Any populations found should be reported to the appropriate Natural Heritage program with information on the natural communities at the site and their edaphic conditions, and the number and vigor of individuals.

\section{ACKNOWLEDGMENTS}

We wish to thank the SouthEast Regional Network of Expertise and Collections (SERNEC) for digital access to collections. We also thank the following herbaria specifically for physical or digital access to specimens in their collections: AUA, CM, DSC, DUKE, F, FLAS, FNPS, FSU, FTG, GA, GH, HBG, IND, K, LSU, MICH, MISSA, MMNS, MO, MPU, NCU, NY, P, SEL, TENN, TEX, TROY, UNA, US, USCH, USF, UWAL, UWFP, VSC, VT (and any that we have inadvertently overlooked). ARF thanks Keith Bradley, Kent Perkins (FLAS), Brett Jestrow (FTG), Lydia Cuni (FTG), Amy Weiss (NY), Barbara Thiers (NY), and Arian Farid (USF) for assistance 
in his sections. KRB and JS thank John Nelson (USCH) for assistance in their section. JMK thanks Malissa Briggler, Theo Witsell, and John Kartesz for assistance in his section. We also thank Melanie Schori and Richard Abbott for valuable reviews which improved the manuscript. We thank the Radford \& Radford Trust at the North Carolina Botanical Garden for funds supporting open access publication of this work. We especially thank an anonymous conservation philanthropist for supporting taxonomic work at the University of North Carolina at Chapel Hill Herbarium (NCU) to clarify the taxonomy of potentially rare and imperiled species in the southeastern United States.

\section{REFERENCES}

Avery, G.N. \& L.K. Loope. 1980. Endemic taxa in the flora of south Florida. South Florida Research Center Report T-558.

BAlLEY, L.H. 1893. Notes on Carex - XVII. Bull. Torrey Bot. Club 20:417-429.

BALL, P.W., \& A.A. REZnICEK. 1993. Carex. In: Flora of North America Editorial Committee, eds. Flora of North America north of Mexico. Oxford University Press, New York, New York, U.S.A., and Oxford, U.K. 23:274-572.

Berry, P.E., R. Rinna, J.A. Peirson, Y. Yang, V.W. Steinmann, D.V. Geltman, J.J. Morawetz, \& N.I. Cacho. 2016. Euphorbia. In: Flora of North America Editorial Committee. 2016. Flora of North America north of Mexico. Volume 12, Magnoliophyta: Vitaceae to Garryaceae. Oxford Univ. Press, New York, New York, U.S.A.

Bickford, D., D. J.Lohman, N.S. Sodhi, P.K. NG, R. MeIER, K. WinkLer, \& I. Das. 2007. Cryptic species as a window on diversity and conservation. Trends Ecol. Evol. 22:148-155.

BRITTON, N.L. 1903. A new Waltheria from the Bahamas. Torreya 3:105-106.

BRITTON, N.L. \& C.F. MilLspaUGH. 1920. The Bahama flora. New York Botanical Garden, Bronx, New York, U.S.A.

BRITTON, N.L. \& J.N. Rose. 1930. Family 23. Caesalpiniaceae. North American Flora 23:201-349.

BURCH, D.G. 1965. A taxonomic revision of the genus Chamaesyce (Euphorbiaceae) in the Caribbean. Ph.D. dissertation, University of Florida, Gainesville, Florida, U.S.A.

BURCH, D.G. 1966. Two new species of Chamaesyce (Euphorbiaceae), new combinations, and a key to the Caribbean members of the genus. Ann. Missouri Bot. Gard. 53:90-99.

CHAFIN, L.G. 2007. Field guide to the rare plants of Georgia. State Botanical Garden of Georgia, Athens, Georgia, U.S.A.

CHALKER-SCOTT, L. 1999. Environmental significance of anthocyanins in plant stress responses. Photochem. \& Photobiol. 70:1-9.

Chapman, A.W. 1860. Flora of the Southern United States. Ivison, Phinney, \& Co., New York, New York, U.S.A.

Chapman, A.W. 1878. An enumeration of some plants-chiefly from the semi-tropical regions of Florida-which are either new, or which have not hitherto been recorded as belonging to the flora of the southern states. Bot. Gaz. 3:2-6, 9-12, 17-21.

CorrelL, D.S. \& H.B. Correl. 1982. Flora of the Bahama archipelago. A.R. Gantner Verlag KG, Vaduz, Liechtenstein.

CRonquist, A. 1949. Noteworthy plants of Georgia. Castanea 14:101-108.

EPA (U.S. Environmental Protection Agency). 2003. Level III Ecoregions of the Continental United States. National Health and Environmental Effects Research Laboratory, EPA.

ESRI. 2017. ArcGIS. Version 10.5. Environmental Systems Research Institute, Redlands, California, U.S.A.

FERNALD, M.L. 1942. Critical notes on Carex. Rhodora 44:281-331, 333-334.

FERNALD, M.L. 1950. Gray's manual of botany, eighth (centennial) edition. Corrected printing, 1970. D. Van Nostrand Co., New York, New York, U.S.A.

Freid, E., J. Francisco-Ortega, \& B. Jestrow. 2014. Endemic seed plants in the Bahamian archipelago. Bot. Rev. (Lancaster) 80:204-230.

GILLIS, W.T. 1974. Name changes for the seed plants in the Bahama flora. Rhodora 76:67-138.

GLEASON, H.A. 1952. The new Britton and Brown illustrated flora of the northeastern United States and adjacent Canada. New York Botanical Garden and Hafner Press, Bronx, New York, U.S.A.

GLEASON, H.A. \& A. CRONQUIST. 1991. Manual of vascular plants of northeastern United States and adjacent Canada, second edition. New York Botanical Garden, Bronx, New York, U.S.A.

GodfreY, R.K. \& J.W. Wooten. 1979. Aquatic and wetland plants of southeastern United States, monocotyledons. University of Georgia Press, Athens, Georgia, U.S.A.

HAINES, A.A. 2011. New England Wildflower Society's Flora Novae Angliae, a manual for the identification of native and naturalized higher vascular plants of New England. New England Wildflower Society and Yale Univ. Press, New Haven, Connecticut, U.S.A. 
Herndon, A. 1993. Notes on Chamaesyce (Euphorbiaceae) in Florida. Rhodora 95:352-68.

IRWIN, H.S. \& R.C. BarnebY. 1982. The American Cassiinae. Mem. New York Bot. Gard. 35:455-918.

IsLEY, D. 1975. Leguminosae in the United States: II. Subfamily Caesalpinioideae. Mem. New York Bot. Gard. 25:1-228.

ISELY, D. 1998. Native and naturalized Leguminosae (Fabaceae) of the United States (exclusive of Alaska and Hawaii). Monte L. Bean Life Science Museum, Brigham Young University, Provo, Utah, U.S.A.

KARTESZ, J.T. 2015. North American plant atlas. (http://bonap.net/napa). Floristic Synthesis of North America, Version 1.0. Biota of North America Program (BONAP), Chapel Hill, North Carolina, U.S.A.

Keener, B.R., A.R. Diamond, L.J. Davenport, P.G. Davison, S.L. Ginzbarg, C.J. Hansen, C.S. Major, D.D. Spaulding, J.K. Triplett, \& M. Woods. 2021. Alabama Plant Atlas. [S.M. Landry and K.N. Campbell (original application development), Florida Center for Community Design and Research. University of South Florida]. University of West Alabama, Livingston, Alabama, U.S.A.

LADD, D. \& J.R. ThомAs. 2015. Ecological checklist of the Missouri flora for Floristic Quality Assessment. Phytoneuron 2015-12:1-274.

LEDIN, R.B. 1953. John Loomis Blodgett (1809-1853). Tequesta 13:23-33.

MACKENZIE, K.K. 1931-1935. Poales, Cyperaceae, Cypereae (pars). North American flora 18(1-7):1-478.

McCune, B. \& M.J. Mefford. 2011. PC-ORD. Multivariate analysis of ecological data. Version 6. MjM Software, Gleneden Beach, Oregon, U.S.A.

NatureServe. 2020. NatureServe Explorer: An online encyclopedia of life [web application]. Version 7.1. NatureServe, Arlington, Virginia, U.S.A. Available http://explorer.natureserve.org. (Accessed: December 8, 2020)

Northrop, A.R. 1902. Flora of New Providence and Andros. Mem. Torrey Bot. Club 12:1-94.

Pennell, F.W. 1917. The genus Chamaecrista Moench in the United States. Bull. Torrey Bot. Club 44:339-362.

Pullen, T.M. 1963. The Cassia fasciculata complex (Leguminosae) in the United States. Ph.D. dissertation, University of Georgia, Athens, Georgia, U.S.A.

Radford, A.E., H.E. Ahles, \& C.R. Bell. 1968. Manual of the vascular flora of the Carolinas. University of North Carolina Press, Chapel Hill, North Carolina, U.S.A.

ReZnicek, A.A. 1993. Carex sect. Lupulinae. In: Flora of North America Editorial Committee, eds. Flora of North America north of Mexico. Oxford University Press, New York, U.S.A., and Oxford, U.K. 23:511-514.

Reznicek, A.A. \& P.W. Ball. 1974. The taxonomy of Carex series Lupulinae in Canada. Canad. J. Bot. 52:2387-2399.

Rhoads, A.F. \& T.A. BLock. 2007. The plants of Pennsylvania: An illustrated manual. Second edition. Univ. of Pennsylvania Press, Philadelphia, Pennsylvania, U.S.A.

Robinson, B.L. \& M.L. Fernald. 1908. Gray's new manual of botany, a handbook of the flowering plants and ferns of the central and northeastern United States and adjacent Canada. $7^{\text {th }}$ edition, illustrated. American Book Company, New York, New York, U.S.A.

RoSE, J.N. 1899. Synopsis of the North American species of Waltheria. Contr. U.S. Natl. Herb. 5:183-185.

SAUNDERS, J.G. 1995. Systematics and evolution of Waltheria (Sterculiaceae-Hermannieae). Ph.D. dissertation, University of Texas at Austin, Austin, Texas, U.S.A.

SAUNDERS, J.G. 2011. Resurrection of the Maui endemic Waltheria pyrolifolia (Sterculiaceae, Hermannieae). Darwiniana 49:76-85.

SAUnders, J.G. 2015. Waltheria. In: Flora of North America Editorial Committee, eds. Flora of North America north of Mexico. Oxford University Press, New York, New York, U.S.A., and Oxford, U.K. 6:212-215.

Schafale, M.P. 2012. Guide to the natural communities of North Carolina, 4th approximation. North Carolina Natural Heritage Program, Department of Environment and Natural Resources, Raleigh, North Carolina, U.S.A.

SchwARTZ, F.C. 2003. Zigadenus. In: Flora of North America Editorial Committee, eds. Flora of North America north of Mexico. Oxford Univ. Press, New York, New York, U.S.A., and Oxford, U.K. 26:81-88.

SMALL, J.K. 1903. Flora of the southeastern United States: Being descriptions of the seed-plants, ferns and fern-allies growing naturally in North Carolina, South Carolina, Georgia, Florida, Tennessee, Alabama, Mississippi, Arkansas, Louisiana and the Indian territory and in Oklahoma and Texas east of the one-hundredth meridian. Published by the author, New York, New York, U.S.A.

SMALL, J.K. 1913. Flora of the Florida Keys: Being descriptions of the seed-plants growing naturally on the islands of the Florida Reef from Virginia Key to Dry Tortugas. Published by the author, New York, U.S.A.

SMALL, J.K. 1919. Chamaecrista deeringiana. Addisonia 4:1-2, pl. 121.

SMALL, J.K. 1933. Manual of the southeastern flora: being descriptions of the seed plants growing naturally in Florida, 
Alabama, Mississippi, eastern Louisiana, Tennessee, North Carolina, South Carolina and Georgia. University of North Carolina Press, Chapel Hill, North Carolina, U.S.A.

SORRIE, B.A. \& S.W. LeONARD. 1999. Noteworthy records of Mississippi vascular plants. Sida 18:889-908.

SorRIE, B.A. \& A.S. WeAKLEY. 2001. Coastal Plain vascular plant endemics: phytogeographic patterns. Castanea 66:50-82. Tennessee Flora Committee. 2015. Guide to the vascular plants of Tennessee. Editors: E.W. Chester, B.E. Wofford, J. Shaw, D.

Estes, and D.H. Webb. University of Tennessee, Knoxville, Tennessee, U.S.A.

UTTAL, L.J. 1971. A defense of Carex intumescens var. fernaldii. Rhodora 73:51-52.

Voss, E.G. \& A.A. ReZnICEK. 2012. Field manual of Michigan flora. University of Michigan Press, Ann Arbor, Michigan, U.S.A. WARD, D.B. 2009. The typification of Crotalaria rotundifolia and Crotalaria maritima (Fabaceae). J. Bot. Res. Inst. Texas $3: 219-225$.

WEAKLEY, A.S. 2020. Flora of the southeastern United States. University of North Carolina Herbarium, North Carolina Botanical Garden, Chapel Hill, North Carolina, U.S.A.

WeAkLey A.S., J.C. LudWIG, \& J.F. Townsend. 2012. Flora of Virginia. Bland Crowder, ed. Foundation of the Flora of Virginia Project Inc., Richmond, Virginia \& Botanical Research Institute of Texas Press, Fort Worth, Texas, U.S.A.

Weakley, A.S., J.C. Ludwig, J.F. Townsend, \& G.P. Fleming. 2020a. Flora of Virginia App. With significant additions and updates. Bland Crowder, ed. Foundation of the Flora of Virginia Project Inc., Richmond, Virginia, U.S.A., and High Country Apps, Bozeman, Montana, U.S.A.

Weakley, A.S., R.J. LeBlond, B.A. Sorrie, C.T. Witsell, L.D. Estes, K.G. Mathews, A. Ebihara, \& K. Gandhi. 2011. New combinations, rank changes, and nomenclatural and taxonomic comments in the vascular flora of the southeastern United States. J. Bot. Res. Inst. Texas 5:437-455.

Weakley, A.S., D.B. Poindexter, R.J. LeBlond, B.A. Sorrie, C.H. Karlsson, P.J. Williams, E.L. Bridges, S.L. Orzell, B.R. Keener, A. Weeks, R.D. Noyes, M. Flores-Cruz, J.T. Diggs, G.D. Gann, \& A.J. Floden. 2017. New combinations, rank changes, and nomenclatural and taxonomic comments in the vascular flora of the southeastern United States. II. J. Bot. Res. Inst. Texas 11:291-325.

Weakley, A.S., D.B. Poindexter, R.J. LeBlond, B.A. Sorrie, E.L. Bridges, S.L. Orzell, A.R. Franck, M. Schori, B.R. Keener, A.R. Diamond, JR., A.J. Floden, \& R.D. Noyes. 2018a. New combinations, rank changes, and nomenclatural and taxonomic comments in the vascular flora of the southeastern United States. III. J. Bot. Res. Inst. Texas 12:27-67.

Weakley, A.S., B.A. Sorrie, R.J. LeBlond, D.B. Poindexter, A.J. Floden, E.E. Schilling, A.R. Franck, \& J.C. Kees. 2018b. New combinations, rank changes, and nomenclatural and taxonomic comments in the vascular flora of the southeastern United States. IV. J. Bot. Res. Inst. Texas 12:461-480.

Weakley, A.S., R.K.S. McClelland, R.J. LeBlond, K.A. Bradley, J.F. Matthews, C. Anderson, \& A.R. Franck. 2019. Studies in the vascular flora of the southeastern United States: V. J. Bot. Res. Inst. Texas 13:107-129.

Weakley, A.S., D.B. Poindexter, H.C. Medford, B.A. Sorrie, C.A. McCormick, E.L. Bridges, S.L. Orzell, K.A. Bradley, H.E. Ballard, JR., R.N. Burwell, S.L. LockHART, \& A.R. Franck. 2020b. Studies in the vascular flora of the southeastern United States. VI. J. Bot. Res. Inst. Texas 14:199-239.

Whetstone, R.D. 1983. The Sterculiaceae in the flora of the southeastern United States. Sida 10:15-23.

Wunderlin, R.P. \& B.F. Hansen. 2011. Guide to the vascular plants of Florida, third edition. University Press of Florida, Gainesville, Florida, U.S.A.

Wunderlin, R.P., B.F. Hansen, A.R. Franck, \& F.B. Essig. 2021. Atlas of Florida Plants (http://florida.plantatlas.usf.edu/).

YANG, Y. \& P.E. BerRY. 2011. Phylogenetics of the Chamaesyce clade (Euphorbia, Euphorbiaceae): reticulate evolution and long-distance dispersal in a prominent C4 lineage. Amer. J. of Bot. 98:1486-1503.

Yang, Y., R. Rina, J.J. Morawetz, T. Haevermans, X. Aubriot, \& P.E. Berry. 2012. Molecular phylogenetics and classification of Euphorbia subgenus Chamaesyce (Euphorbiaceae). Taxon 61:764-789. 